GA-A 13168

(GA-LTR-16)

UC-77

\title{
STRONTIUM TRANSPORT DATA FOR HTGR SYSTEMS
}

by

B. F. MYERS and W. E. BELL

Prepared under

Contract AT(04-3)-167

Project Agreement No. 17

for the

San Francisco Operations Office

U.S. Atomic Energy Commission

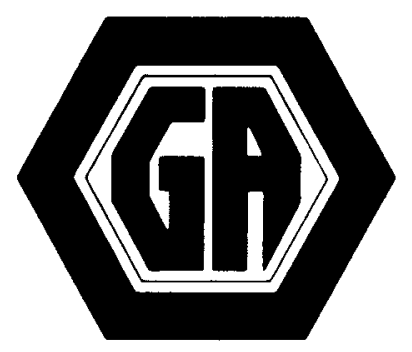

GENERAL ATOMIC 


\section{DISCLAIMER}

This report was prepared as an account of work sponsored by an agency of the United States Government. Neither the United States Government nor any agency Thereof, nor any of their employees, makes any warranty, express or implied, or assumes any legal liability or responsibility for the accuracy, completeness, or usefulness of any information, apparatus, product, or process disclosed, or represents that its use would not infringe privately owned rights. Reference herein to any specific commercial product, process, or service by trade name, trademark, manufacturer, or otherwise does not necessarily constitute or imply its endorsement, recommendation, or favoring by the United States Government or any agency thereof. The views and opinions of authors expressed herein do not necessarily state or reflect those of the United States Government or any agency thereof. 


\section{DISCLAIMER}

Portions of this document may be illegible in electronic image products. Images are produced from the best available original document. 


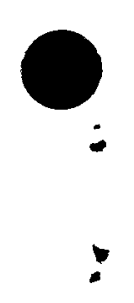

w

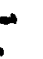

0

. 


\section{FOREWORD}

This is a status report on strontium transport data applicable to high-temperature gas-cooled reactors (HTGRs). The data are being confirmed and extended through work in progress. 
$\bullet$

:

. 


\section{CONTENTS}

1. SUMMARY . . . . . . . . . . . . . . . . . . . . . . 1-1

2. INTRODUCTION . . . . . . . . . . . . . . . . . . . 2-1

3. REFERENCE DATA . . . . . . . . . . . . . . . . . 3-1

4. TRANSPORT IN COATED FUEL PARTIClES . . . . . . . . . . . . . 4-1

4.1. Diffusion in Fuel Kernels . . . . . . . . . . . 4-1

4.1.1. In-Pile Retention Tests . . . . . . . . . . 4-1

4.1.2. Postirradiation Anneals . . . . . . . . . . 4-3

4.1.3. Selection of Reference Data for Diffusion of

Strontium in Fuel Kernels ... . . . . 4-6

4.2. Diffusion in Pyrocarbon . . . . . . . . . . . . 4-9

4.2.1. Postirradiation Anneals . . . . . . . . . 4-9

4.2.2. Diffusion in Unirradiated (Wafer) Samples . . . 4-10

4.2.3. Selection of Reference Data for Diffusion

of Strontium in Pyrocarbon... . . . . . . 4-10

5. SORPTION IN FUEL ROD MATRIX AND GRAPHITE . . . . . . . . . . . 5-1

5.1. Description of Sorption . . . . . . . . . . . 5-1

5.1.1. Sorption Isotherms . . . . . . . . . . 5-1

5.1.2. Sorption Ratio ............... . 5-3

5.2. Measurement Techniques .. . . . . . . . . 5-3

5.3. Sorption on Graphite . . . . . . . . . . . . 5-4

5.3.1. Isotherm Measurements . . . . . . . . 5-4

5.3.2. Suppression of Vapor Pressure of Strontium by $\mathrm{CO}$. . . . . . . . . . . . . . 5-7

5.3.3. Effect of Irradiation . . . . . . . . . . 5-10

5.3.4. Effect of Mixed Isotopes . . . . . . . . 5-10

5.4. Selection of Reference Data for Sorption on Graphite . . 5-12

5.5. Sorption on Fuel Rod Matrix . . . . . . . . . . . 5-13

5.6. Selection of Reference Data for Sorption on Fuel Rod

Matrix . . . . . . . . . . . . . 5-16 
6. DIFFUSION IN GRAPHITE WEB . . . . . . . . . . . . . . 6-1

6.1. Measurement Techniques . . . . . . . . . . . 6-1

6.1.1. Plane Source Diffusion Method . . . . . . . 6-1

6.1.2. Permeation Method . . . . . . . . . . 6-2

6.1.3. In-Pile Diffusion . . . . . . . . . . . 6-2

6.1.4. Loss of Fission Products from Uranium-Loaded

Graphite Samples . . . . . . . . . . 6-3

6.2. Diffusion Coefficient Data . . . . . . . . . . 6-4

6.2.1. Concentration Dependence of the Diffusion

Coefficient . . . . . . . . . . . . 6-4

6.2.2. The Mixed Isotope Effect . . . . . . . . 6-11

6.2.3. Penetration Profiles of Diffusant . . . . . . 6-11

6.3. Selection of Reference Data for Diffusion of Strontium

in Graphite . . . . . . . . . . . . . . . 6-13

7. ACKNOWLEDGEMENT . . . . . . . . . . . . . . . . . . . 7-1

8. REFERENCES . . . . . . . . . . . . . . . . . . 8 8-1

FIGURES

2-1. Schematic drawing of the portion of an HTGR system involved

in strontium transport to the primary circuit . . . . . . . 2-2

3-1. Reduced diffusion coefficients for strontium in oxide fuel

kernels . . . . . . . . . . . . . . . . 3-6

3-2. Reduced diffusion coefficients for strontium in carbide fuel

kernels... . . . . . . . . . . . . . . . 3-7

3-3. Diffusion coefficients for strontium in LTI pyrocarbon . . . 3-8

3-4. Diffusion coefficients for strontium in graphite . . . . . . 3-9

3-5. Sorption isotherms for strontium on fuel rod matrix . . . . . 3-10

3-6. Sorption isotherms for strontium on graphite . . . . . . . . 3-11

4-1. Fission product release profile . . . . . . . . . . . . 4-5

4-2. Reduced diffusion coefficients for strontium in oxide fuel

kernels . . . . . . . . . . . . . . . . . 4-7

4-3. Reduced diffusion coefficients for strontium in carbide

fuel kernels . . . . . . . . .. . . . . . . . 4-8

4-4. Diffusion coefficients for strontium in pyrocarbon . . . . . 4-12

5-1. Sorption isotherms for strontium on $\mathrm{H}-327$ graphite . . . . . 5-5

5-2. Dependence of the heat of adsorption on concentration of strontium sorbed on $\mathrm{H}-327$ graphite . . . . . . . . . . 5-8 


\section{FIGURES (Continued)}

5-3. Strontium vapor pressure over H-327 graphite in the presence of $\mathrm{CO}$. . . . . . . . . . . . . . . . . . . . . 5-9

5-4. Sorption of strontium on irradiated graphite . . . . . . . . 5-11

5-5. Isotherms for strontium on fuel rod matrix and graphite at $1500^{\circ} \mathrm{K}$. . . . . . . . . . . . . . . . . 5-15

6-1. Variation of the diffusion coefficient with concentration of strontium in A.G.L.9 graphite at $1000^{\circ} \mathrm{C}$. . . . . . . 6-9

6-2. Concentration dependence of the diffusion coefficient for strontium in graphite at $1000^{\circ} \mathrm{C}$. . . . . . . . . . 6-10

6-3. Strontium diffusion coefficients in graphite . . . . . . . 6-14

\section{TABLES}

3-1. Summary of equations and parameters describing the reference data for strontium transport . . . . . . . . . . . . 3-2

4-1. In-pile retention test data for BISO-coated particles . . . . 4-2

4-2. Kernel diffusion coefficients for strontium calculated from annealing release curves for BISO-coated particles . . . . . 4-4

4-3. Diffusion coefficients for strontium in pyrocarbon . . . . . 4-11

5-1. Sorptivity on matrix material for strontium relative to H-327 graphite .. . . . . . . . . . . . . . 5-14

6-1. Diffusion coefficients for strontium in graphite . . . . . 6-5 


\section{SUMMARY}

Strontium transport data applicable to HTGR systems are assembled and discussed; reference values have been derived from the available data and are presented in the form of equations and parameters suitable for use as input for reactor calculations. The reference data presented cover the following processes: (1) the diffusion of strontium in fuel kernels and in pyrocarbon, (2) sorption of strontium in fuel rod matrix material, (3) sorption of strontium in graphite, and (4) diffusion of strontium in graphite. Transport of the gaseous fission product precursor of strontium-90, krypton-90, is covered in a separate report (Ref. 1). 


\section{INTRODUCTION}

The purpose of this report is to provide the current reference data for use as input in strontium release calculations and to present the basis for selecting the reference data. These data are employed in the FIPER computer codes (Ref. 2) which are used for calculating the release of metallic fission products into the primary coolant circuit of HTGR systems. The data of this report apply to the transport processes taken into account by the computer codes and are presented in a form suitable for use in the codes.

An outline and brief discussion of the transport mechanisms relevant to strontium transport are presented below. In Section 3 of this report, the reference data are assembled both in tabular form and in graphs which may be used to readily obtain the physical data for specific conditions. In the remaining sections, transport in coated fuel particles, sorption in fuel rod matrix and graphite, and diffusion in graphite are discussed.

As shown in Fig. 2-1, the basic steps leading to the release of the meta1 nuclides into the primary circuit of the HTGR system are (1) release from the fuel particles, (2) sorption and diffusion in the fuel rod matrix material, (3) sorption and diffusion in the graphite, and (4) evaporation through the boundary layer into the helium coolant. The particles in the fuel region consist of two types: (1) a BISO coated-fertile particle consisting of a Tho ${ }_{2}$ fuel kernel, an inner buffer coating of low density, pyrolytic carbon and an outer coating of high density, isotropic, pyrolytic carbon and (2) a TRISO coated-fissile particle consisting of a uranium carbide fuel kernel, ard successive coatings of a pyrolytic carbon buffer, an isotropic pyrolytic carbon, silicon carbide and a second isotropic 


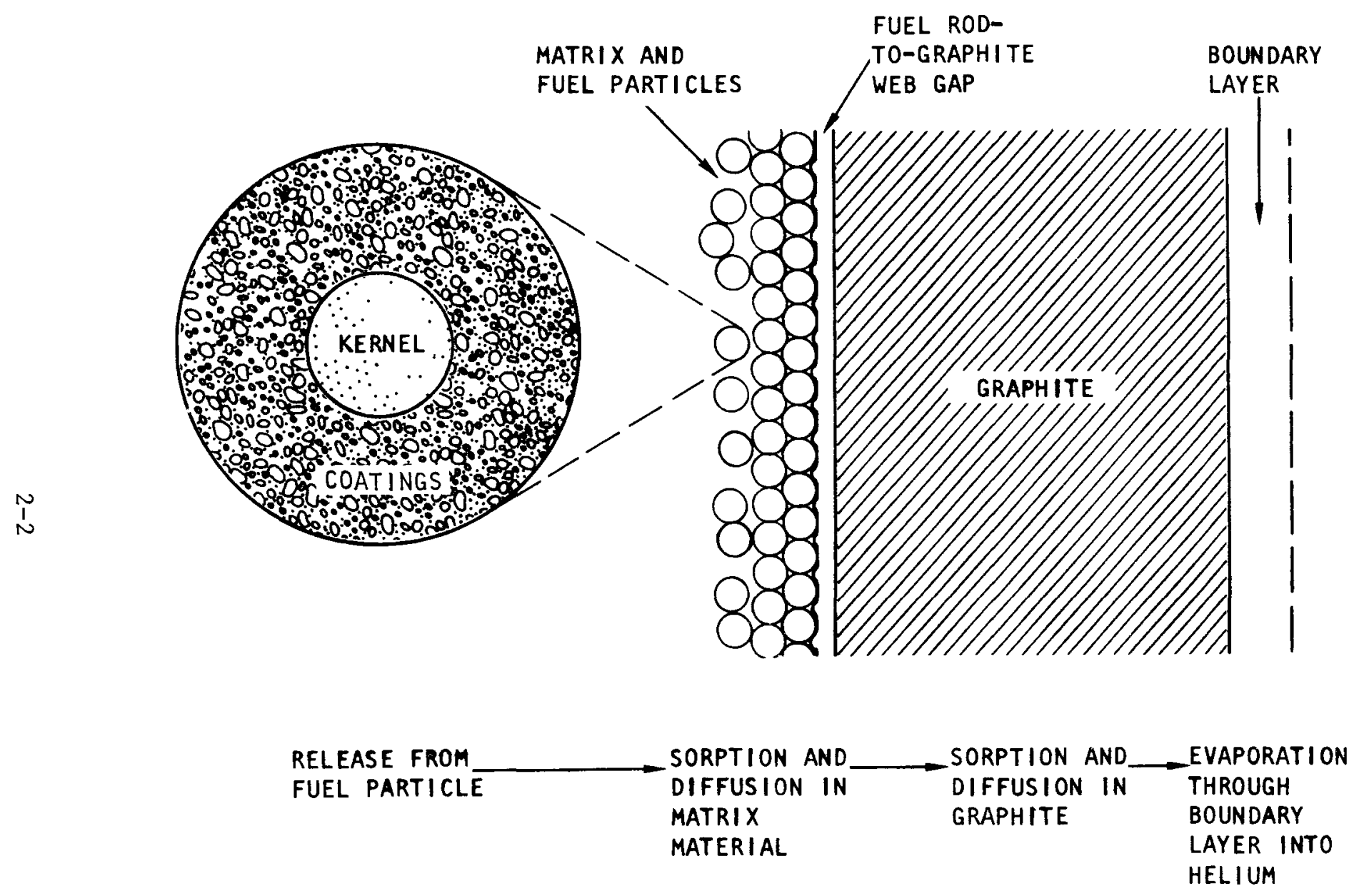

Fig. 2-1. Schematic drawing of the portion of an HTGR system involved in strontium transport to the primary circuit 
pyrolytic carbon. The sources for the release of strontium are (1) fuel contamination in the coatings, (2) fuel contamination in the fuel rod matrix materials, (3) diffusive release from BISO coated-fertile particles, and (4) diffusive release from coated particles with failed coatings. Strontium release into the primary circuit can also occur by decay of the precursor, $\mathrm{Kr}-90$, which in turn is released as a result of fuel contamination and from coated particles with failed coatings. The contribution of krypton-90 along with other gaseous fission products is discussed in another report (Ref. 1).

In presenting the data in the following sections, the assumption has been made that diffusion of strontium through the matrix material surrounding the fuel particle is fast and will not practically limit the strontium release; data for this process are thus excluded here. 


\section{REFERENCE DATA}

Reference data were derived from available data that are considered most suitable for applications to HTGR systems. In the selection of reference data, those data from measurements made under conditions most closely approaching the operating conditions of HTGR systems have been favored, and where judgments on the quality of the data could be made, the data judged most appropriate were heavily weighted.

The reference data presented cover the following processes: (1) the diffusion of strontium in fuel kernels and in pyrocarbon, (2) sorption of strontium in fuel rod matrix material, (3) sorption of strontium in graphite and (4) diffusion of strontium in graphite. The four processes enumerated are discussed in detail in Sections 4 through 6.

Equations and parameters describing the reference data are summarized in Table 3-1. For the diffusion processes in pyrocarbon and in graphite, the description is given as

$$
D=D_{0} \exp \{-Q / R T\}
$$

$$
\text { where } \begin{aligned}
\mathrm{D} & =\text { the diffusion coefficient, } \mathrm{cm}^{2} / \mathrm{sec}, \\
\mathrm{D}_{\mathrm{O}} & =\mathrm{a} \text { constant, } \mathrm{cm}^{2} / \mathrm{sec}, \\
\mathrm{Q} & =\text { the temperature coefficient, cal } / \mathrm{mole}, \\
\mathrm{R} & =\text { the gas constant, } 1.987 \mathrm{cal} /\left(\mathrm{mole}{ }^{\circ} \mathrm{K}\right), \text { and } \\
\mathrm{T} & =\text { the temperature, }{ }^{\circ} \mathrm{K} .
\end{aligned}
$$

In the case of diffusion of strontium in graphite, Eq. 3-1 is valid for strontium concentrations in graphite of $0.7 \mu \mathrm{mole} / \mathrm{g}$ or less. At greater concentrations, the diffusion coefficient increases with increasing concentration; this dependence must be taken into account to 
TABLE 3-1

SUMMARY OF EQUATIONS AND PARAMETERS DESCRIBING

THE REFERENCE DATA FOR STRONTIUM TRANSPORT

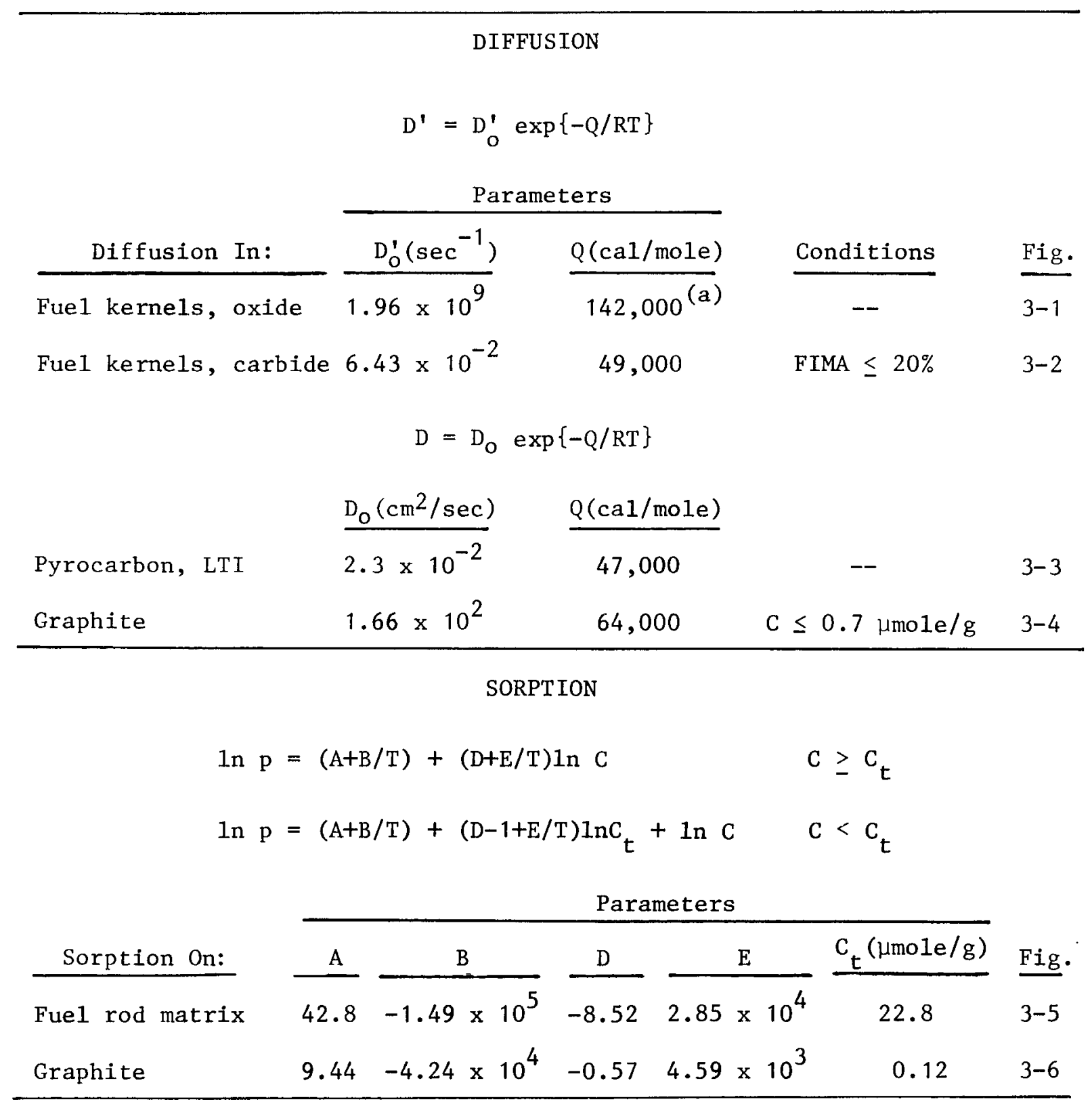

(a) See Section 4.1 .3 for comment on magnitude of this value of $Q$. 
avoid underestimating the extent of strontium transport when concentrations exceed $0.7 \mu \mathrm{mole} / \mathrm{g}$. An empirical description of the dependence of the diffusion coefficient on concentration is given in section 6 .

For diffusion in fuel kernels, the description is given as

$$
D^{\prime}=D^{\prime}{ }_{0} \exp \{-Q / R T\}
$$

where $D^{\prime}=$ the reduced diffusion coefficient, $\sec ^{-1}$, which is given by the ratio of $\mathrm{D} / \mathrm{a}^{2}$,

$a=$ the radius of the equivalent sphere of the particle or grain through which diffusion occurs, $\mathrm{cm}$, and $D^{\prime}{ }_{0}=$ a constant, $\sec ^{-1}$.

For single species sorption processes, the relationship between vapor pressure of strontium and concentration of sorbed strontium is given by

$$
\ln p=(A+B / T)+(D+E / T) \ln C,
$$

where

$$
\begin{aligned}
\mathrm{p} & =\text { the partial pressure of strontium, atm, } \\
\mathrm{C} & =\text { the concentration, Hmole } \mathrm{sr} / \mathrm{g} \text { carbon, and } \\
\mathrm{A}, \mathrm{B}, \mathrm{D} \text { and } \mathrm{E} & =\text { constants as listed in Table } 3-1 .
\end{aligned}
$$

For concentrations of sorbates less than a fixed quantity, $C_{t}$, the pressure dependence changes (from Freundlich to Henrian behavior) and is described by the following relationship:

$$
\ln p=(A+B / T)+(D-1+E / T) \ln C_{t}+\ln C
$$


The sorption of strontium on graphite is increased by irradiation (neutron exposure); this increased sorptivity may be taken into account as described in Section 5.3.3.

The effect of other metallic isotopes on the vapor pressure and diffusion of strontium isotopes in graphite (i.e., the mixed isotope effect) should be taken into account at higher concentrations (see Sections 5.3.4 and 6.2 .2 ).

The types of materials on which the reference expressions of Table 3-1 were based differ from the current reference materials in certain cases. For fuel kernels, the reference kernel material for BISO-coated, fertile particles is $\mathrm{ThO}_{2}$ whereas the measurements were made on oxide kernels composed of $(\mathrm{Th}, \mathrm{U}) \mathrm{O}_{2}$; however, the ratio of thorium to uranium was between 14 and 17. Thus the difference in material is unlikely to be important. Additional experiments are in progress at GA to obtain diffusion coefficients in $\mathrm{ThO}_{2}$. Measurements of sorption on graphite were made primarily on $\mathrm{H}-327$ graphite as were some of the measurements on diffusion in graphite. For sorption, very recent measurements (Ref. 3) made on a reference, near-isotropic graphite, H-451, show no significant difference from previous measurements on H-327 graphite. The measurements of diffusion of strontium in graphite were made on a variety of graphite types but the resulting diffusion coefficients do not have a strong dependence on the type of graphite. Since a type of near-isotropic graphite, $P_{3}$ JHAN, was included in the group of graphites used in the measurements on which the reference data of Table 3-1 are based, the expectation is that measurements of the diffusion coefficient for H-451 graphite will not lead to a significant change in the reference curve.

In the case of the fuel rod matrix material, the formulation of the reference material simulates the Fort St. Vrain fuel rod matrix material on which measurements have been made; thus measurements on the reference material are not expected to yield data significantly different from those for the Fort St. Vrain fuel rod matrix material. 
The four processes as described above are displayed, in terms of Eqs. 3-1 through 3-4, in Figs. 3-1 through 3-6, for conditions that include those generally encountered in HTGR systems under normal operating conditions. The reference curves of Figs. 3-1 through 3-6, in the regions of temperature, pressure, and concentration representative of normal reactor conditions, were obtained for the most part by extrapolation of the available experimental data. 


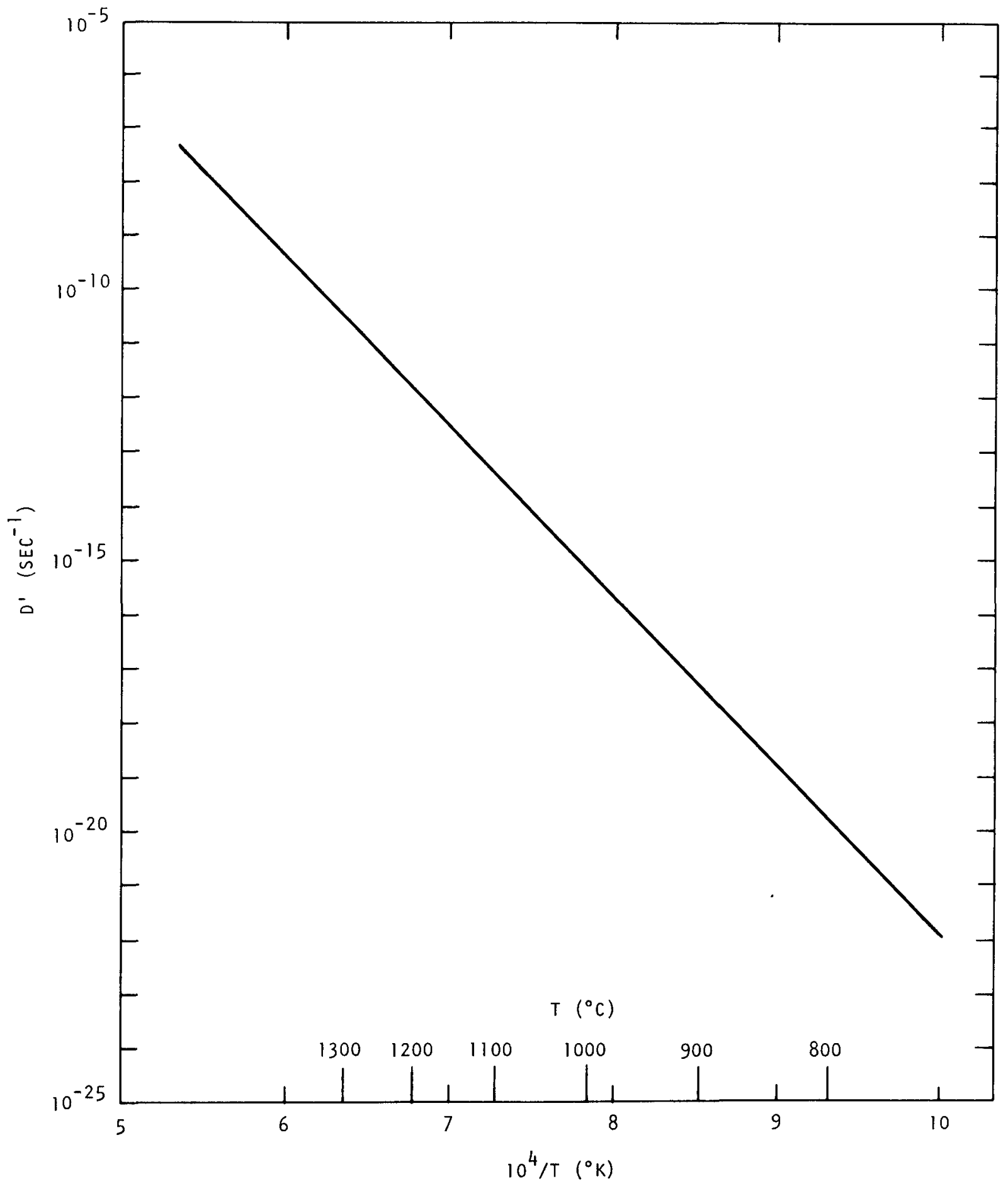

Fig. 3-1. Reduced diffusion coefficients for strontium in oxide fuel kernels 


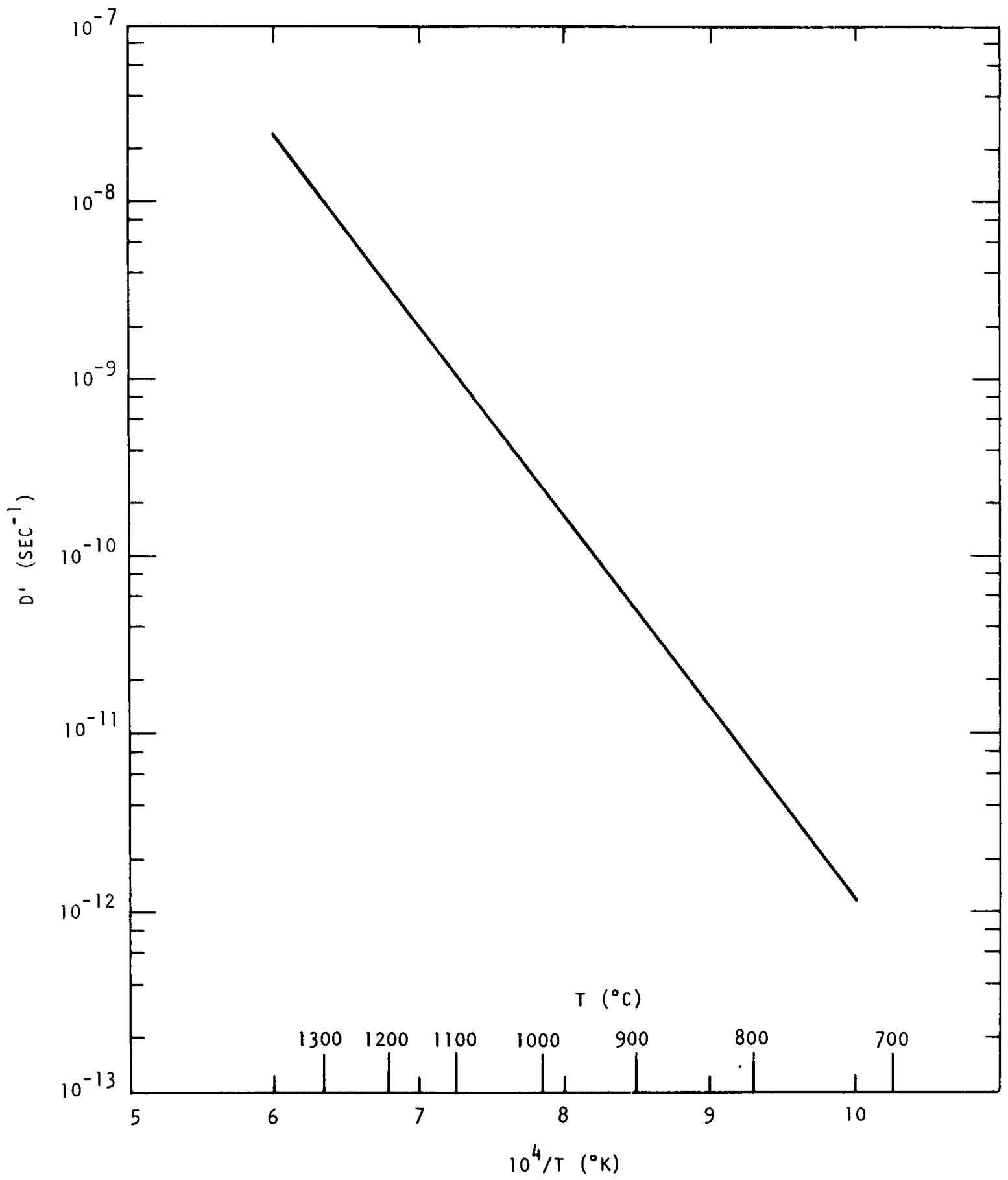

Fig. 3-2. Reduced diffusion coefficients for strontium in carbide fuel kernels 


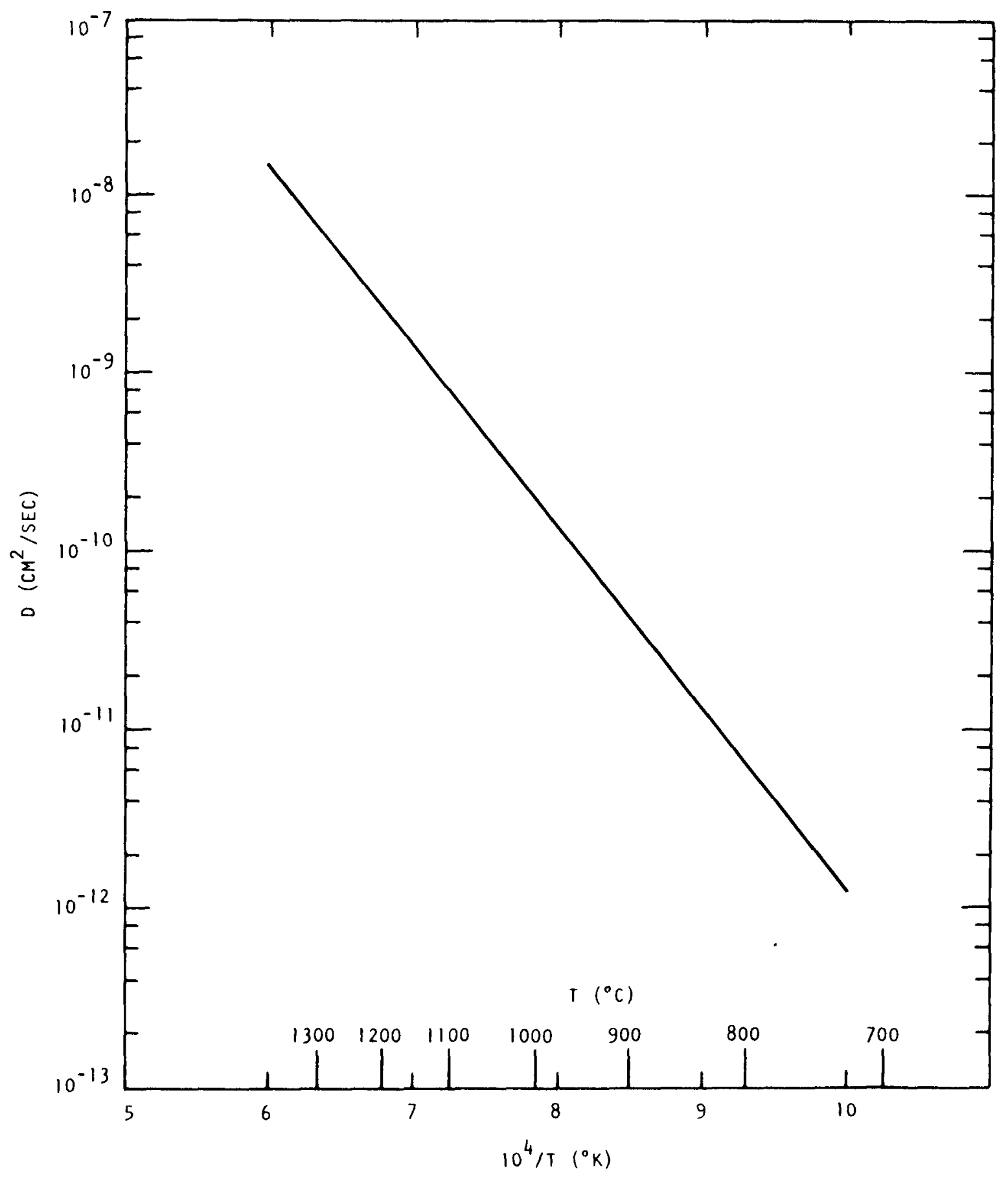

Fig. 3-3. Diffusion coefficients for strontium in LTI pyrocarbon 3-8 


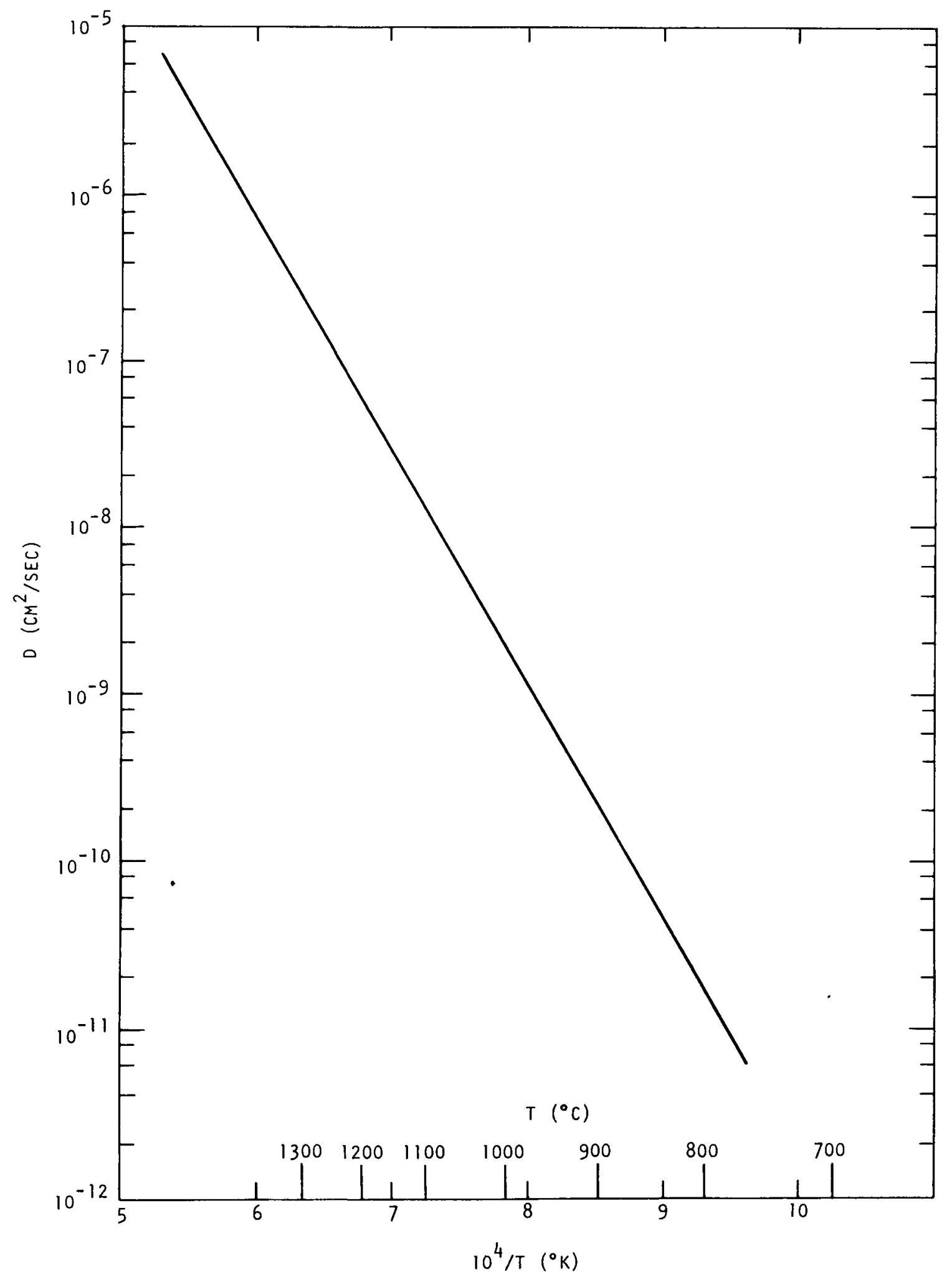

Fig. 3-4. Diffusion coefficients for strontium in graphite 


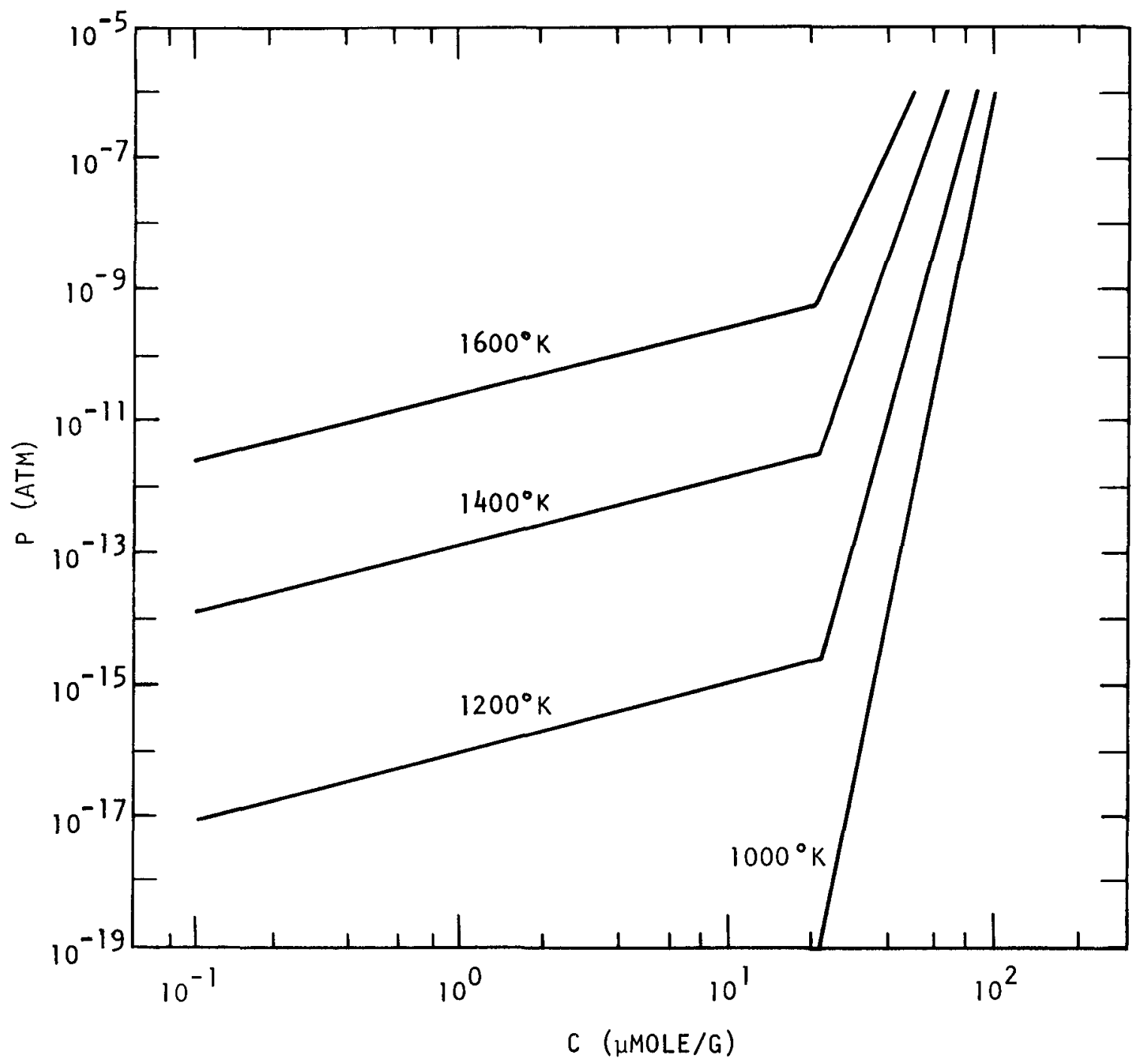

Fig. 3-5. Sorption isotherms for strontium on fuel rod matrix 


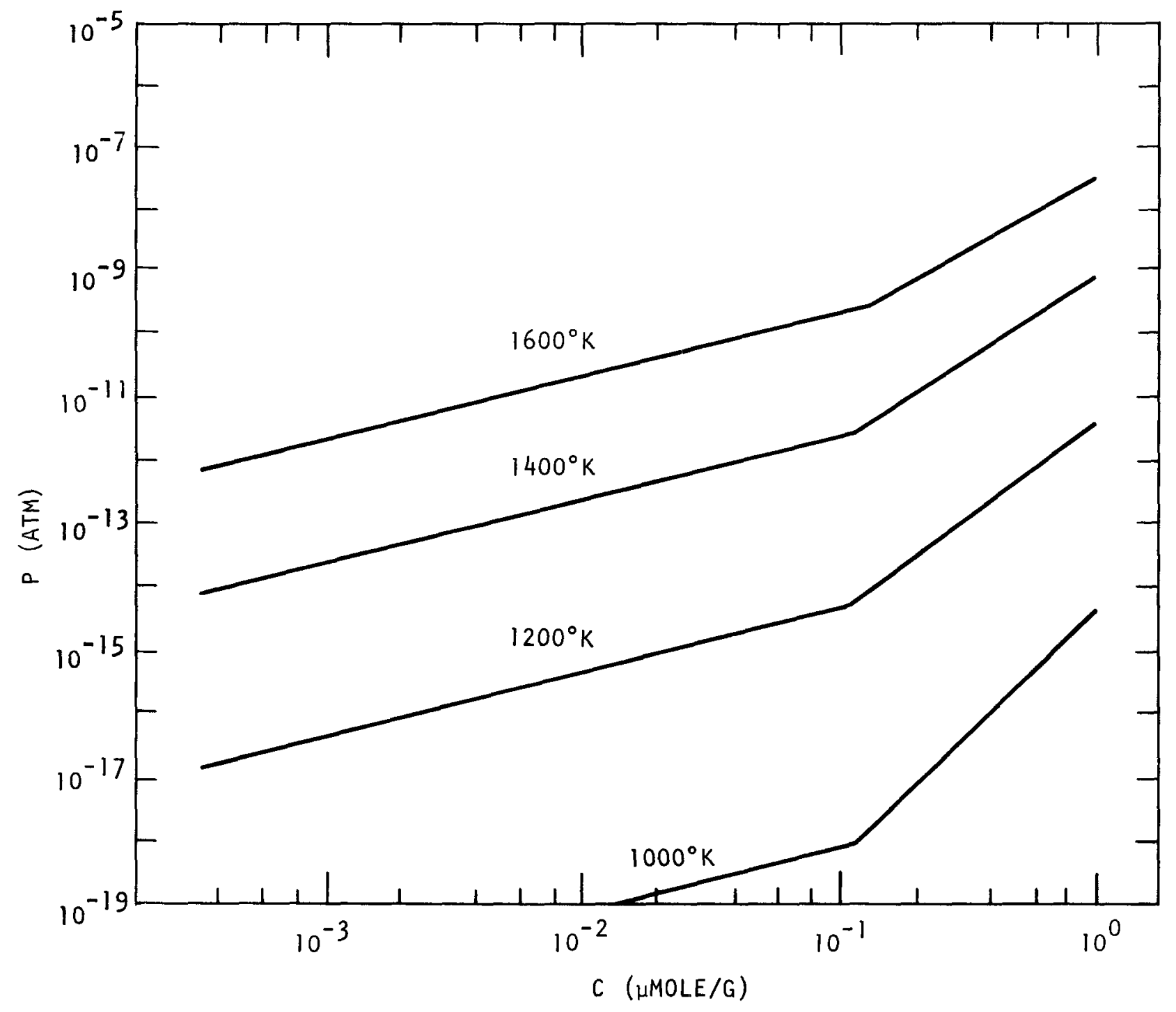

Fig. 3-ó. Sorption isotherms for strontium on graphite 


\section{TRANSPORT IN COATED FUEL PARTICLES}

The release of fission product metals from coated particles involves diffusion in the fuel kernel and in the coatings. The coatings consist of pyrocarbon and silicon carbide. The silicon carbide coating of an intact, TRISO-coated fissile fuel particle retains strontium quantitatively (Ref. 4). Thus strontium release from intact TRISO-coated fuel particles is insignificant compared to the release from other sources (BISO-coated particles, TRISO-coated particles with defective silicon carbide coatings, and fuel contamination). The effectiveness of the silicon carbide coating in containing strontium is most probably a result of the low solubility of strontium in silicon carbide.

4.1. DIFFUSTON IN FUEL KERNELS

Diffusion coefficient data have been derived from in-pile retention tests and laboratory postirradiation anneal tests.

\subsubsection{In-Pile Retention Tests}

In-pile retention of strontium nuclides by BISO-coated fuel particles, irradiated in several General Atomic capsules, was determined by postirradiation measurements. The particle characteristics and the conditions of the irradiation are given in Table 4-1. The retained inventory of strontium nuclides was measured using radiochemical techniques; the number of fissions that occurred (i.e., the quantity of strontium produced) was established from the inventory of zirconium, a non-mobile element, by gamma counting. The in-pile fractional releases of strontium, the complement of the fractions retained, are listed in Table 4-1. Reduced diffusion coefficients (see below) were derived by using expressions presented by Zumwalt 
TABLE $4-1$

IN-PILE RETENTION TEST DATA FOR BISO-COATED PARTICLES

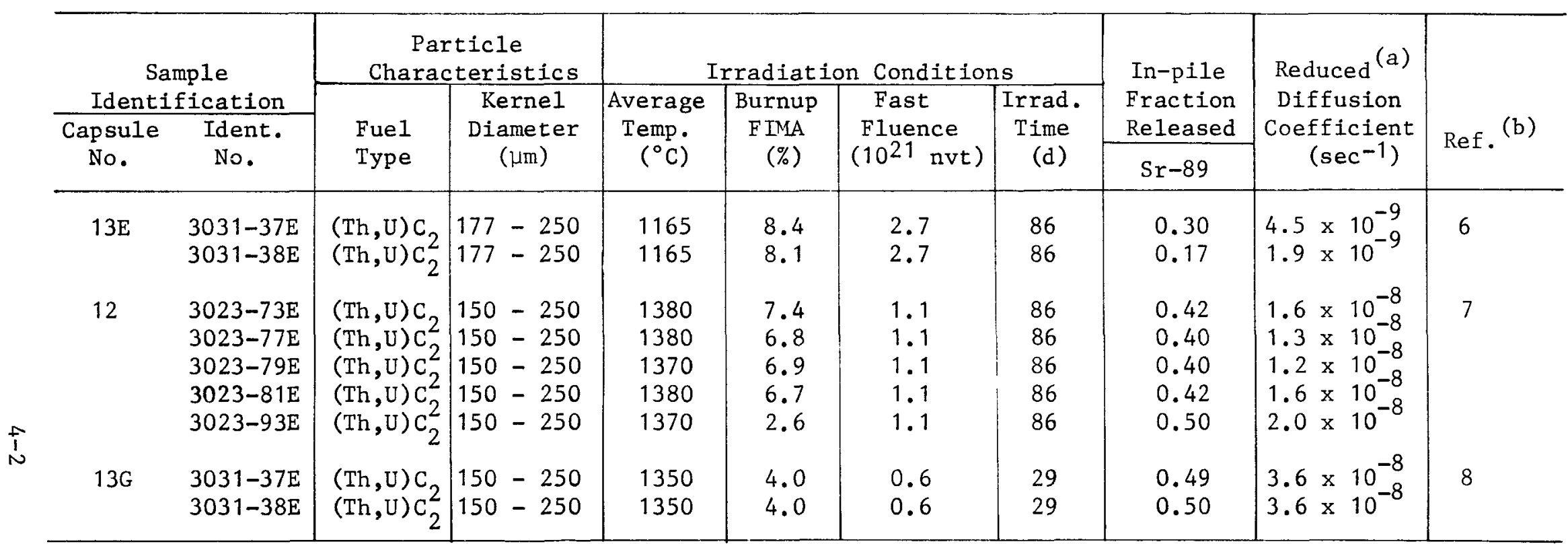

(a) For strontium in fuel kernel.

(b) The characteristics of the fuel particles are from Ref. 5. 
et al. (Ref. 9) relating the fractional release under experimental conditions to the diffusion coefficient, decay constant of the nuclide, and irradiation time.

\subsubsection{Postirradiation Anneals}

Postirradiation annealing measurements were performed on BISO-coated particles and also on one sample of triplex-coated particles* selected from irradiation capsule inventories. The particle characteristics, irradiation conditions, and anneal temperatures are listed in Table 4-2. These particles were given a brief reirradiation in the TRIGA facility to form the short-1ived, strontium-91 isotope; the release of strontium from the particles during the anneal could then be conveniently monitored by gamma counting. For the anneal measurements, the particles were placed in graphite crucibles which were heated in tantalum tubes. Periodically, the strontium-91, which collected in the graphite crucible, was counted. Diffusion coefficients were derived from the time profiles of the fractional release of strontium. The idealized release curve is illustrated in Fig. 4-1(a). For this curve, there is initially a time delay in the observed release followed by a sharp rise to a time region represented by a constant slope. The constant slope corresponds to the steady-state release of the strontium nuclide controlled by diffusion in the kernel. The constant-slope portion of the release curve was used in the following equation to obtain the reduced diffusion coefficient of strontium in the fuel kernel:

$$
D^{\prime}=\frac{D}{a^{2}}=\frac{\pi\left(f-f_{o}\right)^{2}}{36 t},
$$

where $D^{\prime}=$ the reduced diffusion coefficient, $\sec ^{-1}$,

$\mathrm{D}=$ the diffusion coefficient, $\mathrm{cm}^{2} / \mathrm{sec}$,

$a=$ the radius of the equivalent sphere (Ref. 11) of the particle or grain through which diffusion occurs, $\mathrm{cm}$,

$\mathrm{f}=$ the fractional release at time $\mathrm{t}$, and

$\mathrm{f}_{\mathrm{o}}=$ the extrapolated fractional release at zero time.

*Triplex coatings consist of an inner buffer (low density) pyrocarbon layer, an isotropic pyrocarbon layer and an outer granular pyrocarbon layer. 
TABLE 4-2

KERNEL DIFFUSION COEFFICIENTS FOR STRONTIUM CALCULATED FROM ANNEALING RELEASE CURVES FOR BISO-COATED PARTICLES

\begin{tabular}{|c|c|c|c|c|c|c|c|}
\hline \multirow[b]{2}{*}{$\begin{array}{l}\text { Sample } \\
\text { Ident. }\end{array}$} & \multicolumn{2}{|c|}{$\begin{array}{c}\text { Particle } \\
\text { Characteristics }\end{array}$} & \multicolumn{2}{|c|}{$\begin{array}{r}\text { Irradiation } \\
\text { Conditions } \\
\end{array}$} & \multirow[b]{2}{*}{$\begin{array}{c}\text { Anneal } \\
\text { Temp. } \\
\left({ }^{\circ} \mathrm{C}\right)\end{array}$} & \multirow{2}{*}{$\begin{array}{l}\text { Reduced } \\
\text { Diffusion } \\
\text { Coefficient } \\
\quad\left(\sec ^{-1}\right)\end{array}$} & \multirow[b]{2}{*}{$\operatorname{Ref}$. } \\
\hline & $\begin{array}{l}\text { Fue1 } \\
\text { Type }\end{array}$ & $\begin{array}{c}\text { Kernel } \\
\text { Diameter } \\
(\mu \mathrm{m})\end{array}$ & $\begin{array}{c}\text { Irrad. } \\
\text { Temp. } \\
\left({ }^{\circ} \mathrm{C}\right)\end{array}$ & $\begin{array}{r}\text { FIMA } \\
(\%)\end{array}$ & & & \\
\hline $2702-57 E^{(b)}$ & $(\mathrm{Th}, \mathrm{U}) \mathrm{O}_{2}$ & $240-300$ & 1165 & 3.0 & 1400 & $1.2 \times 10^{-9}$ & 3 \\
\hline $2702-57 \mathrm{E}$ & $(\mathrm{Th}, \mathrm{U}) \mathrm{O}_{2}^{2}$ & $240-300$ & 1165 & 3.0 & 1550 & $8.9 \times 10^{-9}$ & 3 \\
\hline $2702-57 E$ & $(\mathrm{Th}, \mathrm{U}) \mathrm{O}_{2}^{2}$ & $240-300$ & 1165 & 3.0 & 1650 & $3.0 \times 10^{-1}$ & 3 \\
\hline $3023-99 E$ & $(\mathrm{Th}, \mathrm{U}) \mathrm{O}_{2}$ & $300-420$ & 1600 & 2.5 & 1400 & $2.9 \times 10^{-10}$ & 3 \\
\hline $3023-99 E$ & $(\mathrm{Th}, \mathrm{U}) \mathrm{O}_{2}^{2}$ & $300-420$ & 1600 & 2.5 & 1550 & $6.8 \times 10^{-9}$ & 3 \\
\hline $3222-71 \mathrm{E}$ & $(\mathrm{Th}, \mathrm{U}) \mathrm{C}_{2}$ & $150-250$ & -- & 0 & 1400 & $3.9 \times 10^{-9}$ & 3 \\
\hline $3222-71 \mathrm{E}$ & $(\mathrm{Th}, \mathrm{U}) \mathrm{C}_{2}^{2}$ & $150-250$ & 685 & 5.7 & 1400 & $1.3 \times 10_{-7}^{-7}$ & 3 \\
\hline $3222-71 \mathrm{E}$ & $(\mathrm{Th}, \mathrm{U}) \mathrm{C}_{2}^{2}$ & $150-250$ & 950 & 5.6 & 1400 & $2.3 \times 10^{-7}$ & 3 \\
\hline $3222-105 E$ & $(\mathrm{Th}, \mathrm{U}) \mathrm{C}_{2}$ & $300-420$ & -- & 0 & 1400 & $4.6 \times 10_{-8}^{-9}$ & 3 \\
\hline $3222-105 \mathrm{E}$ & $(\mathrm{Th}, \mathrm{U}) \mathrm{C}_{2}^{2}$ & $300-420$ & 950 & 1.5 & 1550 & $4.9 \times 10^{-8}$ & 3 \\
\hline $3363-117 \mathrm{E}$ & $(\mathrm{Th}, \mathrm{U}) \mathrm{C}_{2}$ & $300-420$ & 1310 & 5.7 & 1400 & $2.6 \times 10^{-8}$ & 3 \\
\hline $3363-117 \mathrm{E}$ & $(T h, U) C_{2}^{2}$ & $300-420$ & 1310 & 5.7 & 1550 & $3.0 \times 10^{-8}$ & 3 \\
\hline $4000-632 E$ & $(\mathrm{Th}, \mathrm{U}) \mathrm{C}_{2}$ & $150-250$ & -- & 0 & 1400 & $5.3 \times 10^{-8}$ & 3 \\
\hline $4000-660 \mathrm{E}$ & $(\mathrm{Th}, \mathrm{U}) \mathrm{C}_{2}$ & $150-250$ & 975 & 13 & 1400 & $3.4 \times 10^{-8}$ & 3 \\
\hline $4000-695 E$ & $(\mathrm{Th}, \mathrm{U}) \mathrm{C}_{2}$ & $150-250$ & 900 & 0 & 1400 & $8.9 \times 10^{-10}$ & 3 \\
\hline $3031-37 E$ & $(\mathrm{Th}, \mathrm{U}) \mathrm{C}_{2}$ & $177-250$ & - & 4.4 & 2000 & $3.5 \times 10^{-6}$ & 7 \\
\hline $3031-38 E$ & $(\mathrm{Th}, \mathrm{U}) \mathrm{C}_{2}^{2}$ & $177-250$ & -- & 4.4 & 2000 & $1.4 \times 10^{-6}$ & 7 \\
\hline $2813-141 \mathrm{E}$ & $(\mathrm{Th}, \mathrm{U}) \mathrm{C}_{2}$ & $150-250$ & -- & 20 & 1100 & $1.6 \times 10^{-9}$ & 10 \\
\hline $2813-141 \mathrm{E}$ & $(\mathrm{Th}, \mathrm{U}) \mathrm{C}_{2}^{2}$ & $150-250$ & -- & 20 & 1300 & $4.8 \times 10^{-9}$ & 10 \\
\hline $2813-141 \mathrm{E}$ & $(\mathrm{Th}, \mathrm{U}) \mathrm{C}_{2}^{2}$ & $150-250$ & -- & 20 & 1500 & $4.8 \times 10^{-8}$ & 10 \\
\hline
\end{tabular}

(a) For strontium in fuel kernel.

(b) Sample 2702-57E consists of triplex-coated particles. 


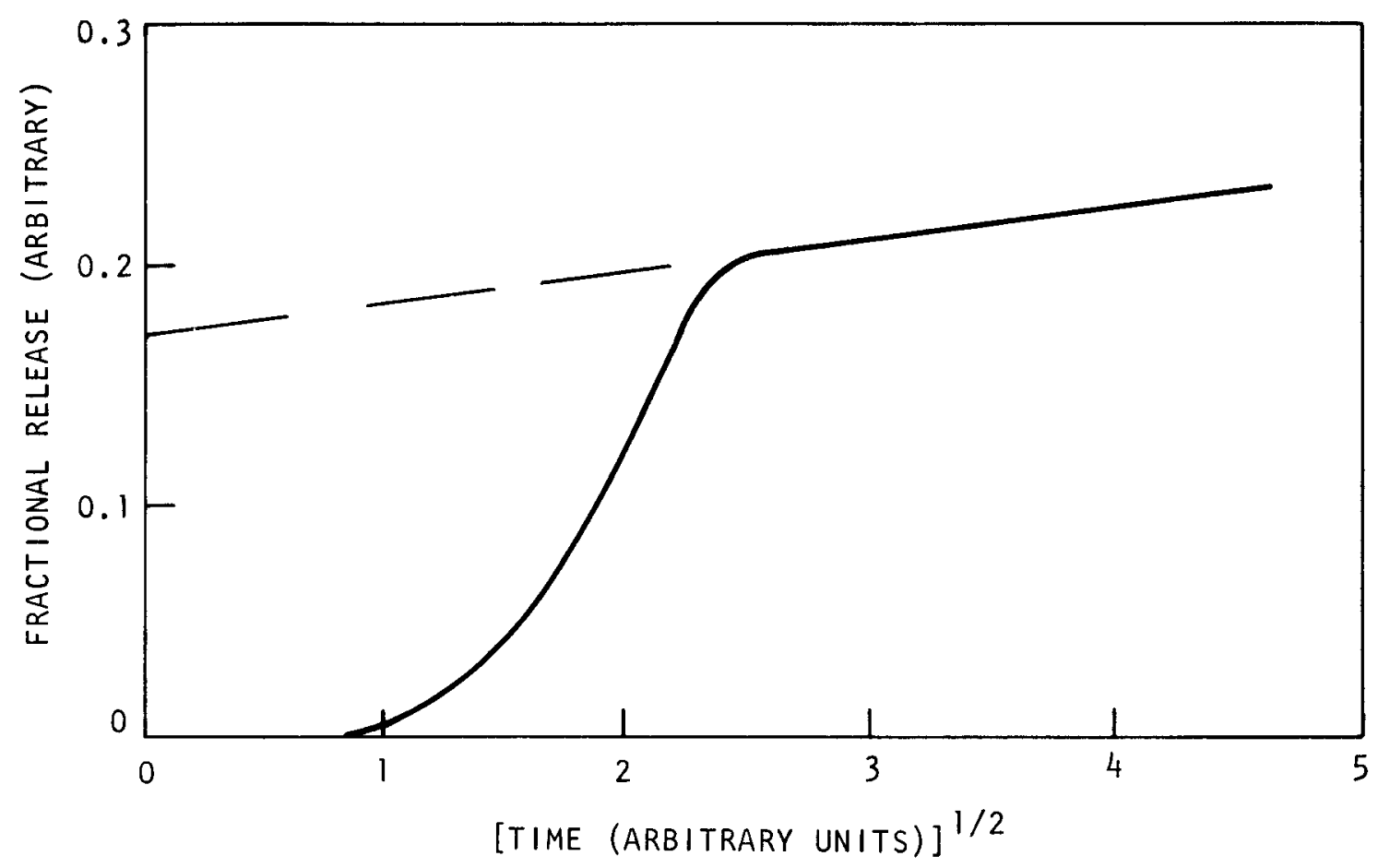

(a)

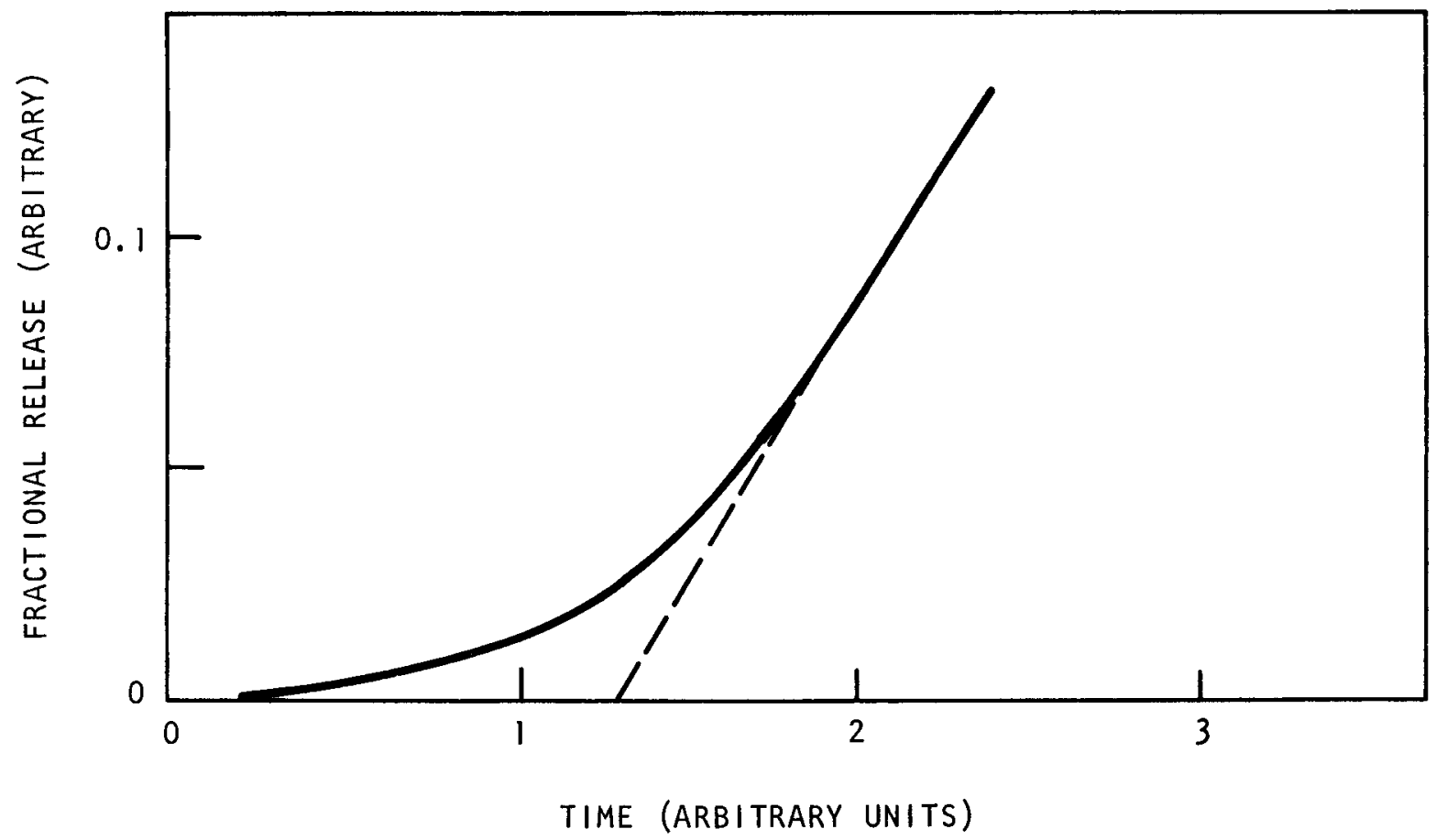

(b)

Fig. 4-1. Fission product release profile 
At zero time, $f_{o}$ can be non-zero; this can result from fission products that have recoiled from the fuel kernel, been released prior to the annea1, or formed from contamination in the particle coatings. Eq. 4-1 is valid for $\mathrm{f}_{\mathrm{o}} \leq 0.15$. The derived reduced diffusion coefficients are given in Table 4-2. For the kernels used both in the postirradiation anneals and the in-pile retention tests, the value of a was equal to or less than approximately $0.001 \mathrm{~cm}$.

\subsubsection{Selection of Reference Data for Diffusion of Strontium in Fuel Kernels}

The reduced diffusion coefficients derived from both in-pile retention tests and postirradiation anneal measurements are plotted in Fig. 4-2 for fuel oxide kernels and in Fig. 4-3 for fuel carbide kernels; the curves shown are the least squares straight lines. For the oxide kernel data shown in Fig. 4-2, the value of the temperature coefficient ( $Q=142 \mathrm{kcal} / \mathrm{mole})$ derived from the least squares fit is unusually large; further experiments are necessary to establish the value of $Q$ confidently. A comparison of the data of Figs. 4-2 and 4-3 clearly demonstrates that strontium is retained to a greater extent by oxide kernels than by carbide kernels at reactor temperatures (i.e., the diffusivity of strontium in oxide kernels is much less than that in carbide kerne1s). Flowers reports (Ref. 12) larger retentivity of strontium by oxide kernels. This is in accord with observations (Ref. 4) on the distribution of fission products in irradiated particles and on fission product release into reactor fuel tubes.

The oxide kernel data of Fig. 4-2 were obtained using particles having burn-up values of $3 \%$ FIMA or less. In carbide kernels, the data used in calculating reduced diffusion coefficients were obtained using particles with a burn-up of $20 \%$ or less. For the data shown in Fig. 4-3, there is no apparent dependence of the diffusion coefficient on FIMA; however, the scatter may wel1 mask such a dependence.

The parameters derived from the least squares straight lines of Figs. 4-2 and 4-3 are 1isted in Table 3-1; these lines and extrapolations of these lines are also shown in Figs. 3-1 and 3-2.

$$
4-6
$$




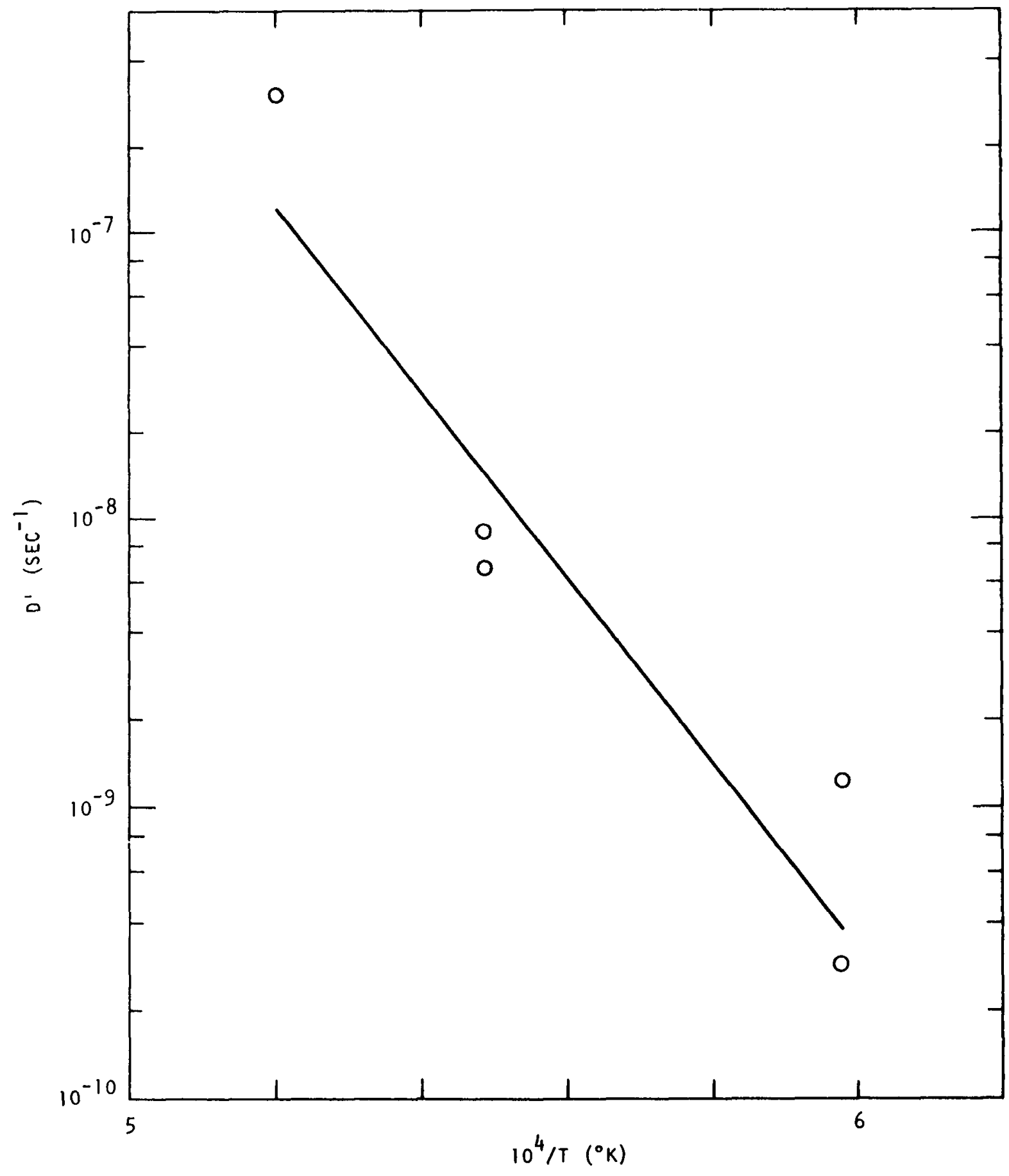

Fig. 4-2. Reduced diffusion coefficients for strontium in oxide fuel kernels $4-7$ 


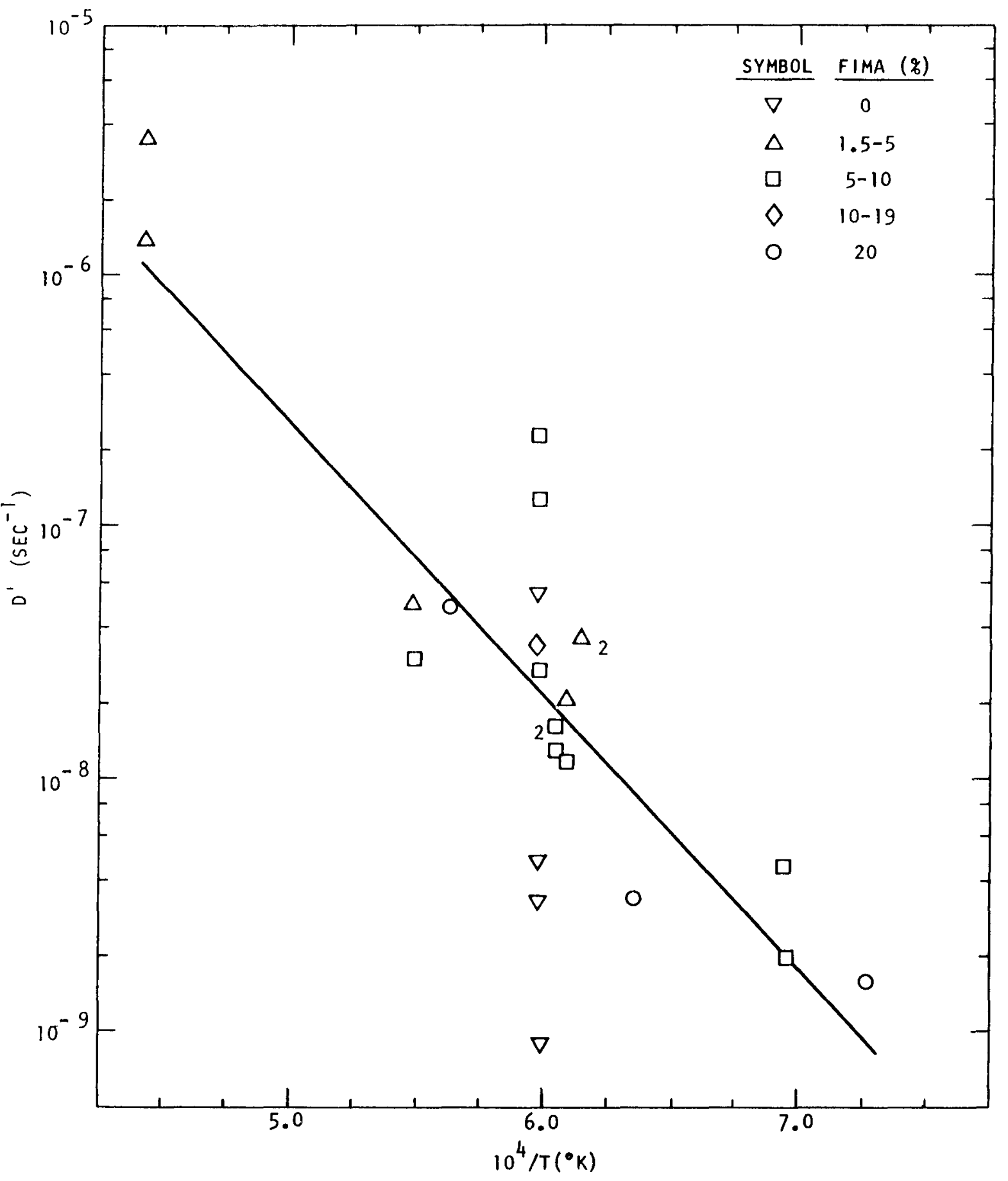

Fig. 4-3. Reduced diffusion coefficients for strontium in carbide fuel kernels 4-8 


\subsection{DIFFUSION IN PYROCARBON}

Diffusion coefficient data for strontium in pyrocarbon have been obtained principally from laboratory anneal tests for both irradiated and unirradiated pyrocarbon. The materials used in these measurements have been of two types: a high temperature, isotropic (HTI) coating which is deposited at temperatures of $1700^{\circ} \mathrm{C}$ or larger from methane decomposition and a low temperature, isotropic (LTI) coating which is deposited at $1300^{\circ} \mathrm{C}$ from decomposition of a mixture of propylene and acetylene. While the LTI coating is the formulation used in fuel particles for the HTGR, data for both HTI and LTI will be considered below since the amount of LTI data is limited.

\subsubsection{Postirradiation Annea1s}

Postirradiation anneal measurements at GA (Ref. 3) were performed using BISO-coated particles as described in Section 4.1.2 above. Diffusion coefficients were derived from these measurements using the relation

$$
\mathrm{D}=\ell^{2} / 6 \tau,
$$

where $\ell=$ the coating thickness, $\mathrm{cm}$, and

$\tau=$ the delay time for the appearance of the diffusant at the outer boundary of the coating, sec.

The delay time, $\tau$, is the value of the intercept on the abscissa of the idealized release curve illustrated in Fig. 4-1(b) and is obtained by extrapolation of the initial, linear portion of the release curve. The analysis of the postirradiation anneal measurements is based on the assumption that the pyrocarbon coating is initially free of diffusant. This assumption requires the irradiation of the particle to be performed at a temperature sufficiently low to prevent all but negligible diffusion of the fission product into the pyrocarbon coating. This requirement is met here by the fact that the diffusant, strontium-91, was formed only after the major irradiation period as described in Section 4.1.2. 
In addition to the measurements at GA, two measurements of the diffusion coefficient of strontium in pyrocarbon were performed at ORNL (Ref. 13) by postirradiation anneal measurements. Aside from differences in apparatus between the GA and ORNL experiments, the major difference was the use of bremsstrahlung measurements to detect Sr-90 during early parts of the anneals before interference from other diffusants made detection of strontium difficult.

\subsubsection{Diffusion in Unirradiated (Wafer) Samples}

The diffusion coefficients of strontium for unirradiated samples were measured (Ref. 14) using thin coatings of pyrolytic carbon, about $100 \mu \mathrm{m}$ in thickness, deposited on porous graphite wafers. Two types of measurements were made: in one case, the coated wafer was placed in a bed of graphite powder containing the strontium diffusant and an anneal then performed. In the other case, the wafer and coating were saturated with an isotope of the diffusant to the extent of 0.2 weight \% and then placed in a bed of graphite powder. In both cases, following the annealing period, the concentration profile of the diffusant in the coating was determined and the diffusion coefficient was derived from the concentration profile. Both methods yielded the same values of the diffusion coefficient within the experimental uncertainty.

\subsubsection{Selection of Reference Data for Diffusion of Strontium in Pyrocarbon}

The diffusion coefficients from the postirradiation anneal and the wafer experiments are 1isted in Table 4-3 and plotted in Fig. 4-4. The plotted data from the wafer experiments are not distinguished for the type of experiment. Also no plotted data are distinguished for the values of FIMA as these limited data do not show a significant dependence on FIMA.

While the LTI coatings are of primary importance for considerations of HTGR operating conditions, these LTI-coating data, as displayed in Fig. 4-4, are too few to yield a reference curve; therefore all the 
TABLE 4-3

DIFFUSION COEFFICIENTS FOR STRONTIUM IN PYROCARBON

Postirradiation Anneal Measurements Using BISO-Coated Particles

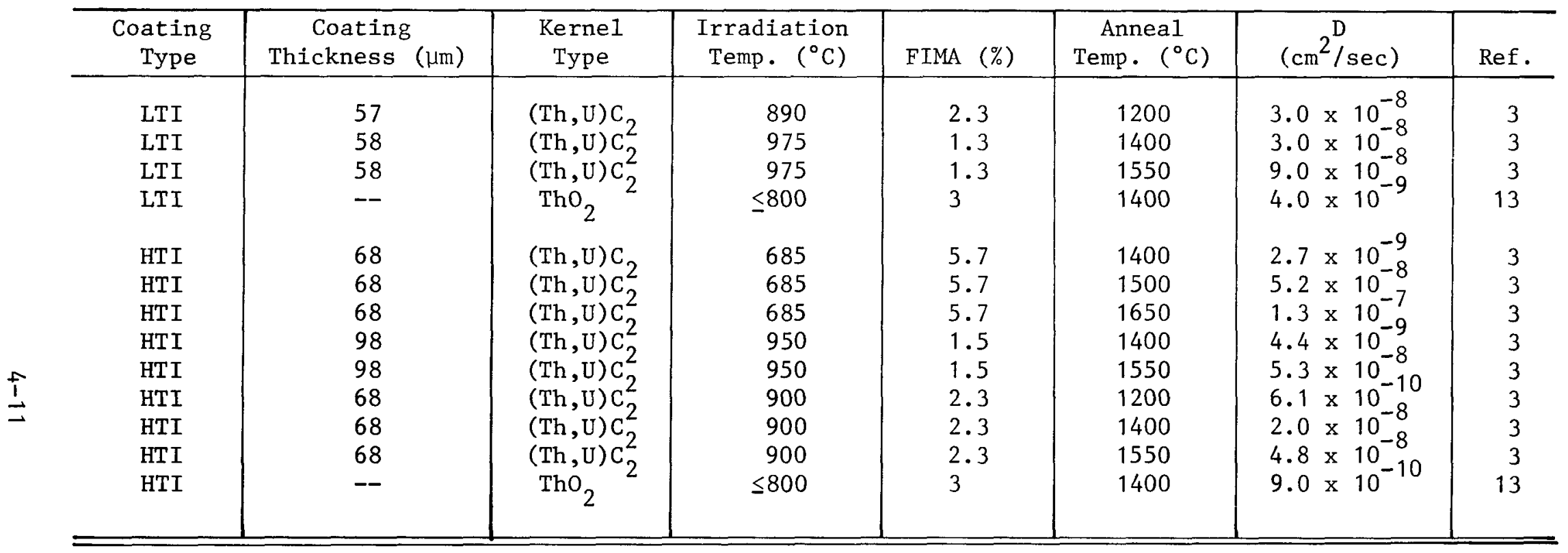

Diffusion in Unirradiated (Wafer) Samples (Coating Type = HTI; Ref. 14)

\begin{tabular}{|c|c|c|}
\hline Anneal Temp. $\left({ }^{\circ} \mathrm{C}\right)$ & $D\left(\mathrm{~cm}^{2} / \mathrm{sec}\right)$ (non-loaded) & $\mathrm{D}\left(\mathrm{cm}^{2} / \mathrm{sec}\right)$ (pre-1oaded) \\
\hline $\begin{array}{l}1000 \\
1100 \\
1200 \\
1300 \\
1400 \\
1500 \\
1700\end{array}$ & $\begin{array}{l}8.0 \times 10^{-10} \\
3.7 \times 10^{-9} \\
1.0 \times 10^{-8} \\
2.3 \times 10^{-8} \\
4.4 \times 10^{-8} \\
\text {-- }\end{array}$ & $\begin{aligned} 8.5 & \times 10^{-11} \\
1.5 & \times 10^{-9} \\
& -- \\
7.8 & \times 10^{-9} \\
& -- \\
4.4 & \times 10^{-8} \\
3.5 & \times 10^{-7}\end{aligned}$ \\
\hline
\end{tabular}




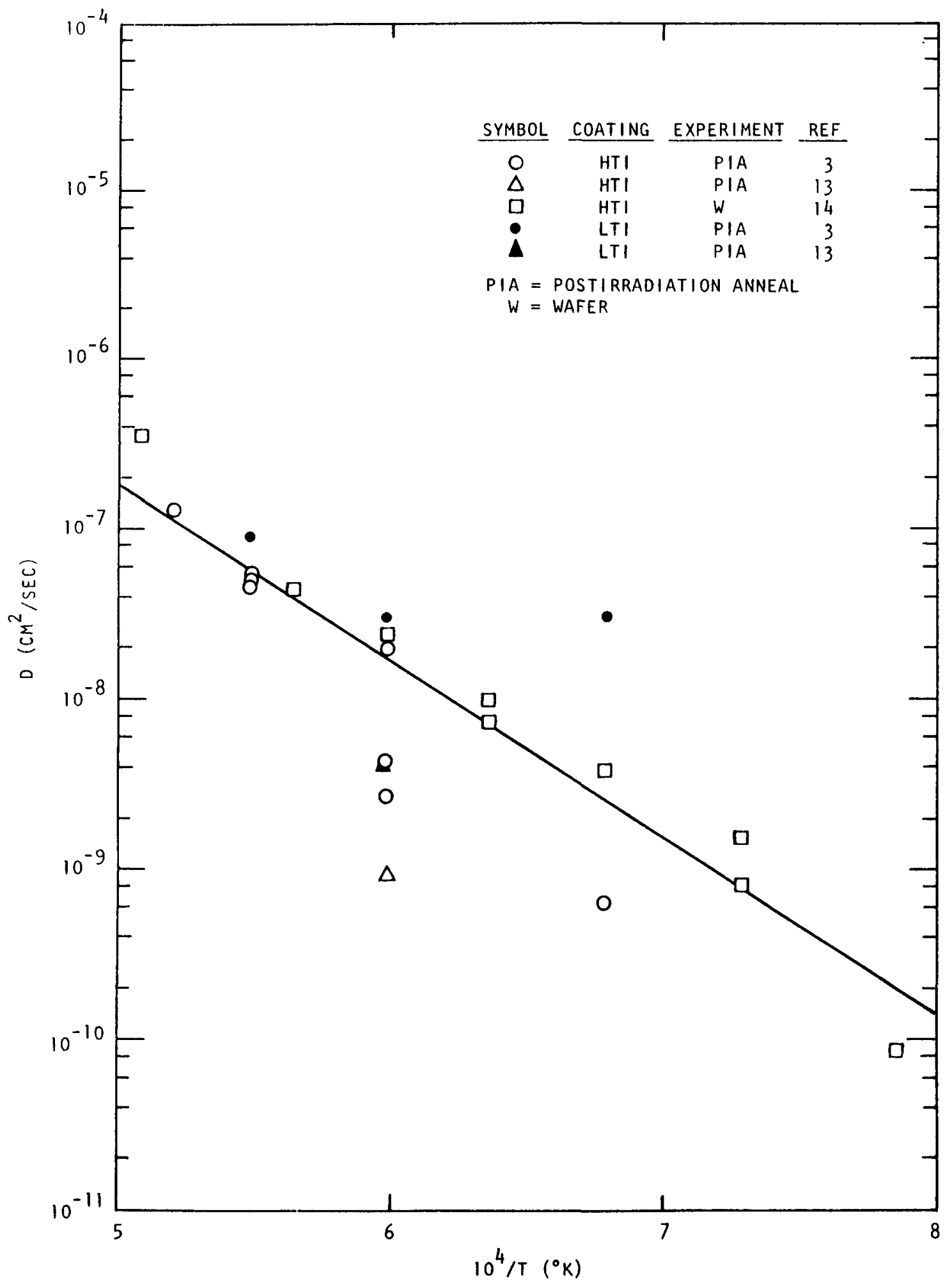

Fig. 4-4. Diffusion coefficients for strontium in pyrocarbon 
data were used to obtain a reference curve. On the basis of the available data, this is a satisfactory procedure since the difference between the HTI- and LTI-coating data for strontium cannot yet be regarded as significant. The reference curve is represented by the least squares straight line shown in Fig. 4-4. The parameters derived from the least squares straight line of Fig. 4-4 are listed in Table 3-1; this 1ine and an extrapolation of this line are shown in Fig. 3-3. 


\section{SORPTION IN FUEL ROD MATRIX AND GRAPHITE}

Metallic fission products released from the fuel particles are assumed to be rapidly dispersed throughout the fuel rod matrix. Transport to the graphite web takes place in the vapor phase across the rod-to-web gap or at random contact points. The concentrations of the fission product metals in the facing surfaces of the matrix and graphite differ. The sorptivity for strontium of a typical matrix material can be quite large relative to that of graphite; this is a potentially important factor leading to reduced fission product release from an HTGR core.

\subsection{DESCRIPTION OF SORPTION}

\subsubsection{Sorption Isotherms}

Within prescribed ranges of concentration, the sorption of metal fission products on sorbents is adequately described by the Freundlich isotherm (Ref. 15); the relationship between vapor pressure and the concentration of sorbed species is used in the form

$$
\ln p=(A+B / T)+(D+E / T) \ln C,
$$

where $\quad \mathrm{p}=$ partial pressure, atm,

$C=$ the concentration of sorbed species, $\mu$ mole/g,

and $A, B, D$, and $E$ are constants determined by a fit of Eq. 5-1 to experimental data.

The heat of adsorption of the sorbed metal, $Q$ (cal/mole), is given in terms of the Freundlich isotherm by

$$
Q=-R \frac{\partial \ln p}{\partial T^{-1}}=-R(B+E \ln C),
$$


where $\mathrm{R}$ is the gas constant. Thus, Freundlich sorption is characterized by an increase in the heat of adsorption with decreasing concentration in the sorbed species.

Conformance to the Freundlich isotherm is limited to an intermediate concentration range. At high concentrations of sorbed metal, when $1 \mathrm{n} C$ has the value $-\mathrm{B} / \mathrm{E}$, Eq. 5-1 predicts a vapor pressure independent of temperature and Eq. 5-2 predicts a zero heat of adsorption. For values of in C near and greater than $-B / E$, experiments (Ref. 16) demonstrate deviation of observed vapor pressure - concentration curves from the curves for the Freundlich isotherm for metal sorbed on graphite. As the concentration of sorbed metal decreases, the heat of adsorption, Q, increases without bound according to Eq. 5-2. However, the magnitude of the heat of adsorption must reach a limit at some concentration. Such a limit is consistent with observations in the cesium-graphite system (Ref. 17) at low concentrations where the isotherm is in accord with Henry's law. The Henrian isotherm is characterized by a constant heat of adsorption and by a direct proportionality between the vapor pressure and the concentration of sorbed species. In the case of the cesium-graphite system, experiments (Refs. 18, 19, 20) indicate that as the concentration decreases the dependence of the vapor pressure on the concentration of sorbate becomes weaker than in the Freundich isotherm case but the dependence is not always sufficiently well characterized to demonstrate a transition to Henrian behavior. To be conservative, the assumption is made that below a fixed concentration of sorbed metal, the vapor pressure is proportional to the concentration, i.e., the relation is that of Henry's law. Thus, Eq. 5-1 becomes, in this concentration region,

$$
\ln p=(A+B / T)+(D-1+E / T) \ln C_{t}+\ln C
$$

where $C_{t}$ is the fixed concentration for the transition from Freundlich to Henrian isotherm regions.

Use of Eq. 5-3 to evaluate Eq. 5-2 demonstrates that Q becomes constant in the concentration range below $\mathrm{C}_{t}$. 


\subsubsection{Sorption Ratio}

A useful parameter in the consideration of release calculations is the sorption ratio, $\phi$. The ratio is defined as

$$
\phi=\frac{\text { concentration of metal in matrix }}{\text { concentration of metal in graphite }} .
$$

Care must be exercised in using $\phi$ since measurements of $\phi$ are usually made under isothermal conditions; under practical conditions the temperature of the fuel rod matrix and the graphite web will differ and the $\phi$ value for isothermal conditions is not strictly applicable. Nevertheless, $\phi$ values are useful in qualitative comparison of various matrix materials and in deducing an isotherm for a sorbent, if $\phi$ values at a series of temperatures are available together with the isotherm of the other sorbent.

\subsection{MEASUREMENT TECHNIQUES}

Sorption measurements have been made by Knudsen cell and isopiestic methods (Ref. 21).

In one Knudsen cell method, a sample of sorbent impregnated with a sorbate is placed in the cell which is placed in a mass spectrometer and brought to the temperature of the experiment. The effusion of the sorbate vapor, which is a negligible perturbation to the equilibrium between the sorbate in the vapor and solid phases, is monitored with the mass spectrometer as a function of time and temperature. The total quantity and the vapor pressure of the sorbate in the cell can be determined with the aid of the time profile of effusing mass and knowledge of the initial and final quantities of sorbate.

In a variation of this Knudsen cell method, a radioactive tracer of the sorbate effusing from the cell is collected on a target and measured (Refs. 17, 22). 
In a second variation of the Knudsen cell method which can be applied to strontium (Ref. 19), the cell consists of two interconnected compartments each having an orifice. Initially, one compartment is loaded only with sorbent while the other compartment has sorbate plus sorbent. At a fixed temperature, the experiment consists of monitoring the approach to an equilibrium distribution of sorbate between the vapor and solid phases in the two compartments. The estab1ishment of an equilibrium distribution can be confirmed by such experiments.

In the usual isopiestic method, the sorbent is placed in a horizontal, stainless-steel section of an evacuated, L-shaped tube; the vertical section contains a source of radioactive sorbate. Both sections of the L-shaped tube can be maintained at fixed but independent temperatures. During a run, the sorbate pressure is fixed by maintaining the source section at a specific temperature. The activity of the sorbate on the sorbent is monitored until equilibrium has been established. A series of runs is carried out by changing the sorbate and/or sorbent temperatures. At the conclusion of the series of runs, the activity on the sorbent is measured in a calibrated counter permitting the previously measured relative activities to be converted to absolute activities. In a variation of the isopiestic method two different sorbents are equilibrated at a fixed temperature and a common vapor pressure of the sorbate. This is accomplished by using a container with two interconnecting compartments in each of which the activity may be measured. The data obtained using this apparatus yields directly a sorption ratio.

\subsection{SORPTION ON GRAPHITE}

\subsubsection{Isotherm Measurements}

The isotherms determined for strontium sorption on graphite are shown in Fig. 5-1 for both GA and Harwell experiments; the graphite type for both experiments was $\mathrm{H}-327$ having grain size in the range $37-74 \mu \mathrm{m}$. For the experiments performed at General Atomic (Ref. 23), the measurements were made using molybdenum knudsen cells in conjunction with a mass spectrometer. 


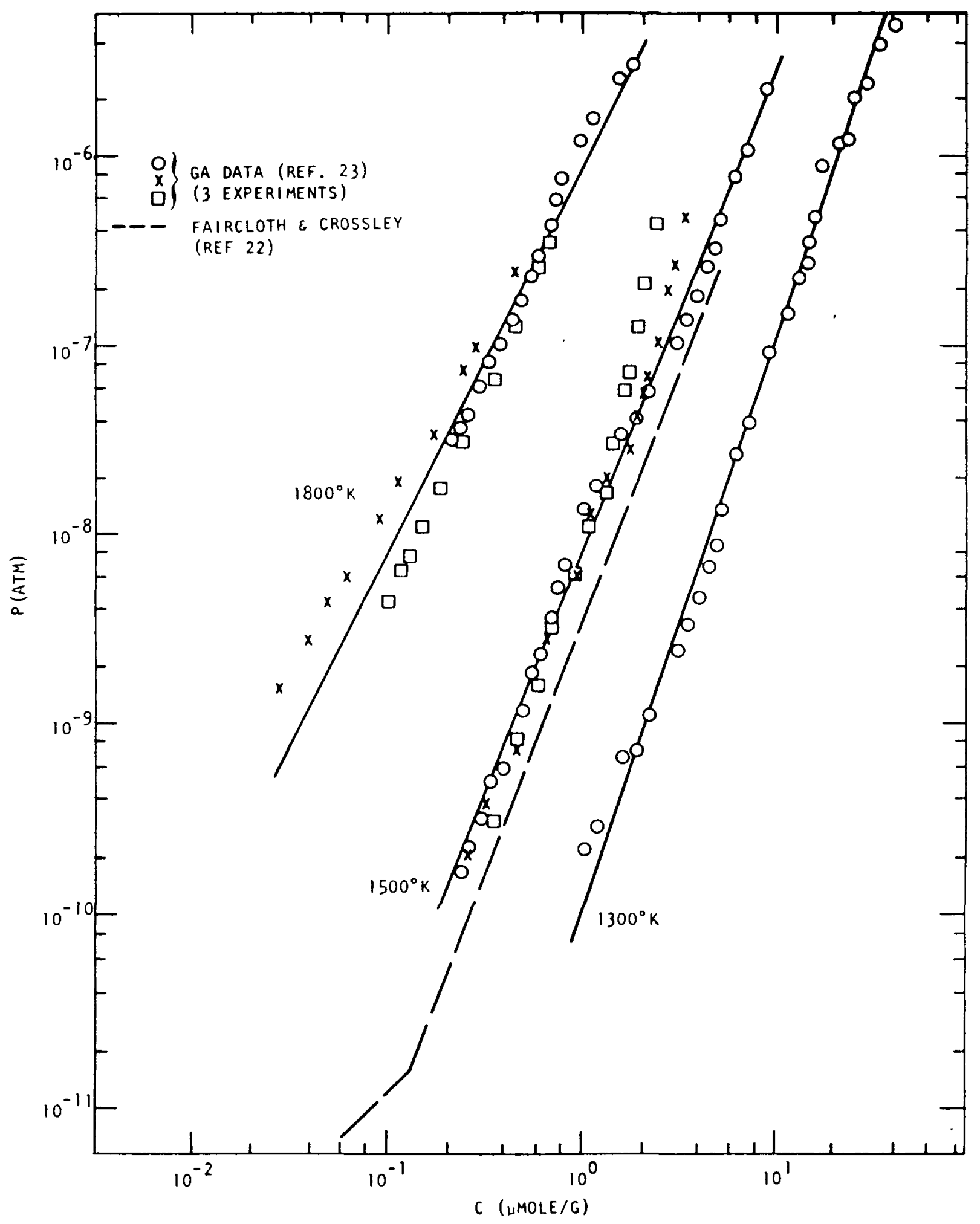

Fig. 5-1. Sorption isotherms for strontium on H-327 graphite 
A representative isotherm from experiments performed at Harwell (Ref. 22) for $1500^{\circ} \mathrm{K}$ is also indicated in Fig. 5-1 by the dashed line. (Only summaries of the Harwell data in the form of least-squares curves are presently available.) Agreement within a factor of three was obtained between the Harwell data and those of General Atomic in the temperature range between 1500 and $1700^{\circ} \mathrm{K}$ and at sorbed concentrations in the Freundlich isotherm region. In the Harwell experiments, a tungsten effusion cell was used with target collection; with this apparatus, measurements could be made at concentrations as low as $2 \times 10^{-4} \mu$ mole/g. These low concentration measurements show a transition to Henrian behavior below about $0.12 \mu \mathrm{mole} / \mathrm{g}$, both at 1500 and $1700^{\circ} \mathrm{K}$. The transition region is indicated in Fig. 5-1. A transition at this concentration is somewhat at variance with the General Atomic isotherm at $1800^{\circ} \mathrm{K}$ which exhibits no indication of a transition over the concentration range which extends to about $3 \times 10^{-2} \mu \mathrm{mole} / \mathrm{g}$; in a more recent experiment at GA in which an isotherm at $1900^{\circ} \mathrm{K}$ was determined, a slight slope change occurred at $0.06 \mu \mathrm{mole} / \mathrm{g}$. A representative curve from the Harwell data was also presented by Flowers et a1. (Ref. 24); the vapor pressures given by Flowers are larger than the values given in Ref. 22 presumably due to the inclusion of a factor to account for a grain size effect.

The effect of grain size of the sorbent has been investigated at General Atomic for several metals (Refs. 18, 25-27). For strontium, recent measurements (Ref. 27) yield no evidence for a grain size effect.

The data of Fig. 5-1 also rough1y agree with earlier measurements of the vapor pressure of strontium over TS-688 graphite (Ref. 28). These earlier measurements were also important in demonstrating that the amount of meta1 associated with the Knudsen cell material was always a small fraction of that sorbed in the graphite (Ref. 29) and that molybdenum and tungsten were acceptable cell materials (Ref. 30). In further experiments (Ref. 28) using the isopiestic ( $L$-shaped tube) technique, difficulties were encountered due to material interactions at the high temperatures required. 
The heat of vaporization, $Q$, derived from the isotherm measurements at General Atomic (Refs. 23, 31) are shown in Fig. 5-2 in agreement with Eq. 5-2. The smallest value measured for the heat of vaporization (about $50 \mathrm{kcal} / \mathrm{mole}$ ) which corresponds roughly to monolayer coverage of the sorbent, is only slightly less than the value of about $54 \mathrm{kcal} / \mathrm{mole}$ reported (Refs. 32, 33) for vaporization of strontium from $\mathrm{SrC}_{2}$. From the Harwell data (Ref. 22), only an average value of the heat of vaporization equal to $91 \mathrm{kcal} / \mathrm{mole}$ is derivable.

\subsubsection{Suppression of Vapor Pressure of Strontium by CO}

The possibility of the presence of $\mathrm{CO}$ in the cell during measurements of strontium isotherms as well as in the HTGR helium coolant at partial pressures below about $5 \times 10^{-4}$ atm raises the question of the effect of the $\mathrm{CO}$ on the vaporization of strontium. In the preparation of samples for Knudsen cell measurements, the sorbent was impregnated with $\mathrm{SrNO}_{3}$ and an in-situ decomposition performed. If a fraction of the strontium were left in the oxide rather than carbide form, subsequent vaporization might lead to $\mathrm{CO}$ as well as strontium vapor (Ref. 23); the formation of CO from degassing of the graphite has been shown (Ref. 23) to be negligible. The results (Ref. 34) of metal vapor pressure measurements in which CO was directly added to the Knudsen cell are shown in Fig. 5-3 for H-327 graphite. The solid lines are reference isotherms which are presumably uninfluenced by the presence of $\mathrm{CO}$. This is indicated by experiments (Ref. 31) yielding results in agreement with the reference isotherms but in which the in-situ decomposition occurred in a tantalum cell that acted as an oxygen getter. The pressures of $\mathrm{CO}$ given in Fig. 5-3 are not accurately known.

The data in Fig. 5-3 indicate that at $1500^{\circ} \mathrm{K}$ there is no significant dependence on the $C O$ pressure over a range in pressure of two orders of magnitude. The indicated reductions in vapor pressure of strontium could be due to experimental uncertainties. At $1300^{\circ} \mathrm{K}$, the reduction in vapor pressure is significant at the higher concentrations of sorbed metal but becomes smaller at lower concentrations. Further experiments on the effect of $\mathrm{CO}$ on the strontium vapor pressure are desirable, particularly under 


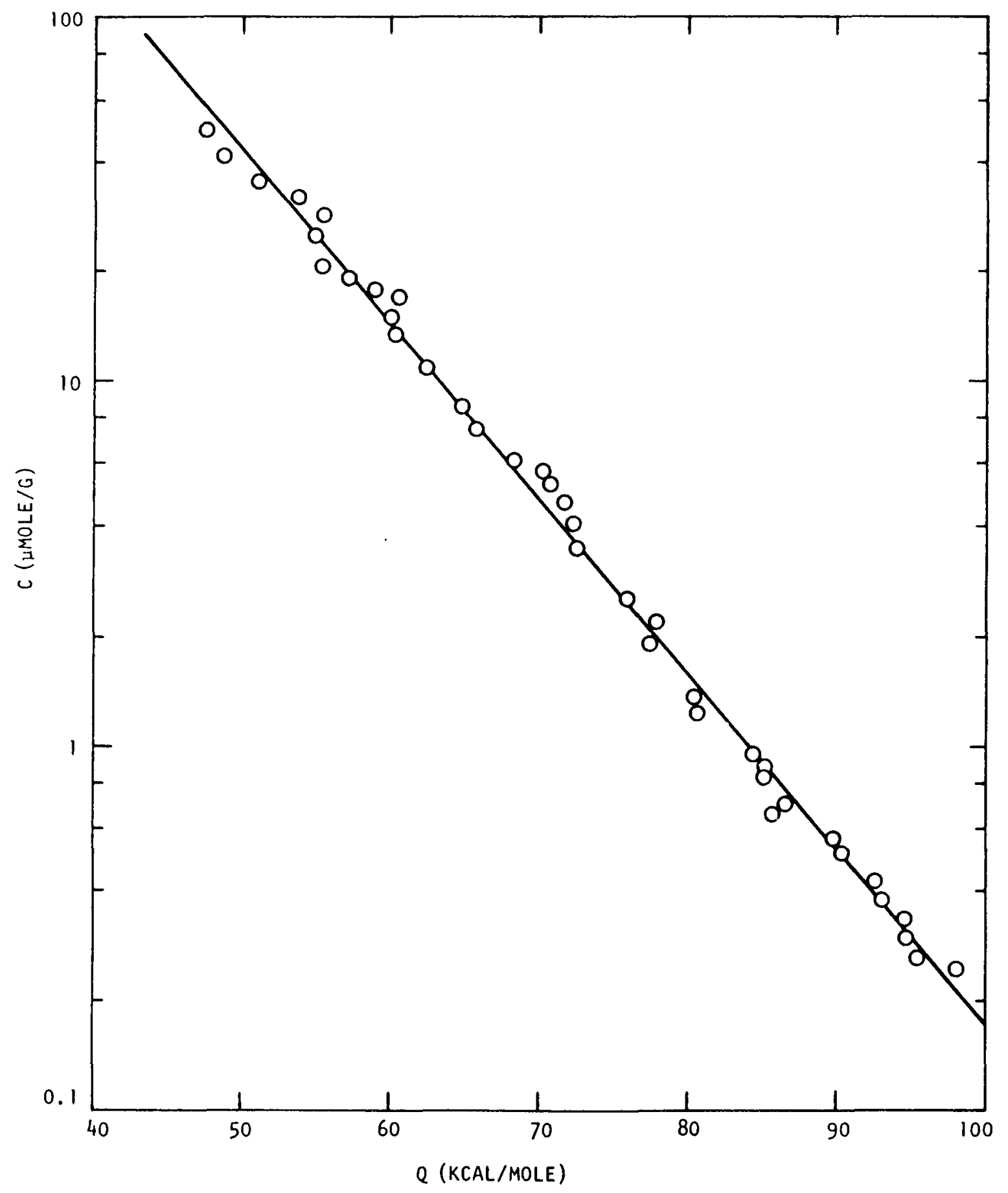

Fig. 5-2. Dependence of the heat of adsorption on concentration of strontium sorbed on $\mathrm{H}-327$ graphite 


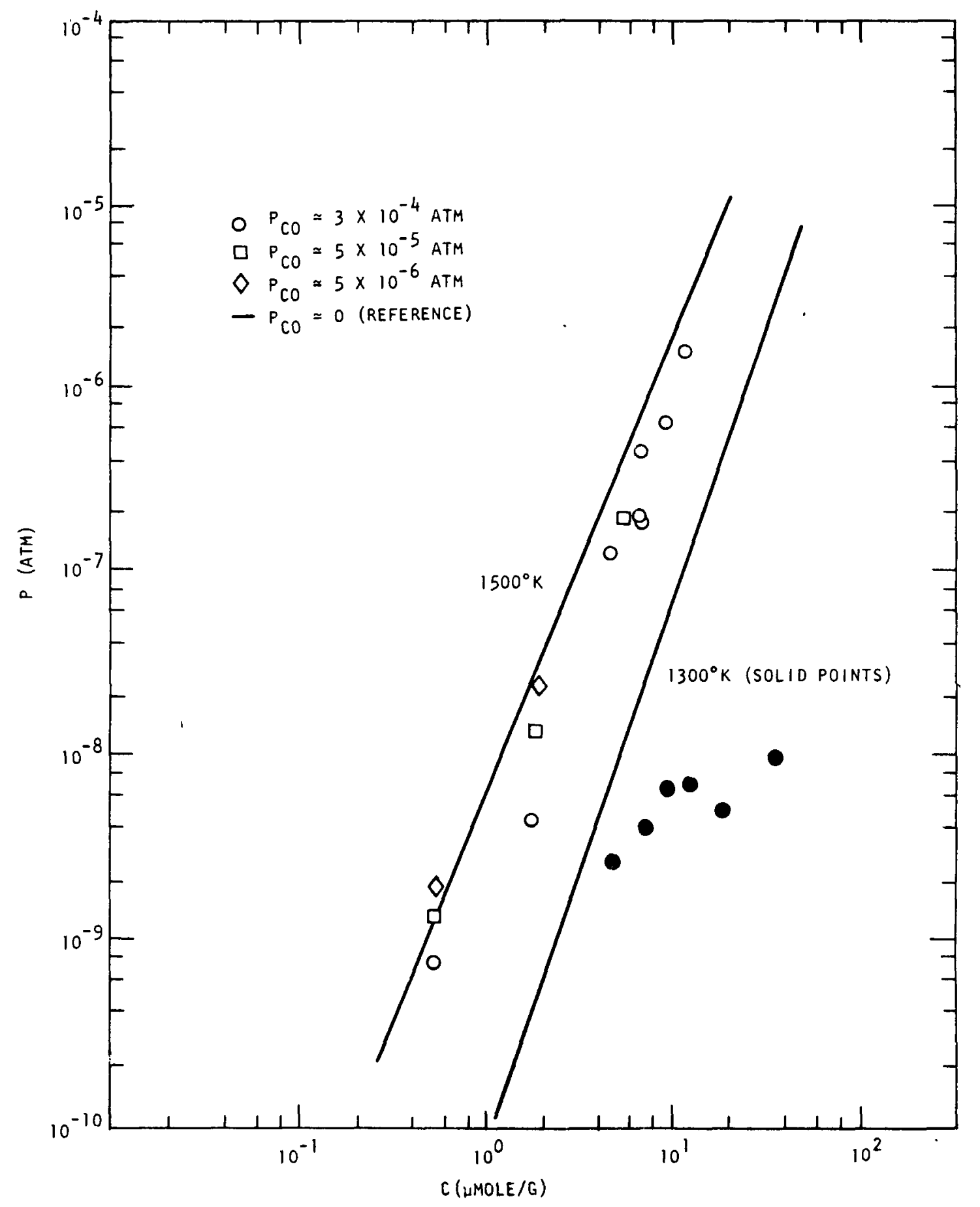

Fig. 5-3. Strontium vapor pressure over H-327 graphite in the presence of CO 
reactor conditions. But, at present, no effect of co has been demonstrated for the lower concentrations of sorbed Sr more appropriate to reactor conditions.

\subsubsection{Effect of Irradiation}

Measurements on samples of graphite that have been irradiated in a reactor show increased sorptivity for metals. Data resulting from measurements (Ref. 35) of the sorption of strontium on TS-688 graphite are shown in Fig. 5-4. The isopiestic method was used to obtain these data. At the highest neutron exposure, the sorptivity of graphite for strontium increased by nearly a factor of seven.

To account for the increased sorptivity of graphite resulting from irradiation, the concentration of sorbate, $\mathrm{C}$ of $\mathrm{Eq} .5-1$, and the transition concentration, $C_{t}$ of $E q$. 5-3, may be replaced by the approximation $C /(1+f)$ and $C_{t} /(1+f)$, respectively, where $f$ is the neutron fluence in units of $10^{21}$ nvt. Such a correction includes the assumptions that the data of Fig. 5-4 will not change with concentration of sorbate or with the temperature under which the sorption in the irradiated graphite occurs. Only limited evidence (Ref. 35) exists that shows no significant change in the slope of the isotherm for irradiated and unirradiated samples of the same graphite in the case of cesium sorption. There is an indication (Ref. 35) that at high temperatures (above $1200^{\circ} \mathrm{C}$ ) annealing of the irradiated graphite may reduce the sorptivity; however, essentially all of the graphite is at a temperature below $1200^{\circ} \mathrm{C}$ during an HTGR operation. The effect of irradiation also depends on the type of graphite (Ref. 36); for the reference near-isotropic graphite, the increase in sorptivity is greater than for TS-688 graphite in the case of cesium sorption. If this relation holds in the case of strontium, use of the data of Fig. 5-4 would be conservative with respect to graphite type.

\subsubsection{Effect of Mixed Isotopes}

When two different metals are sorbed on graphite, the vapor pressure of one or both species may be increased over that found when only 


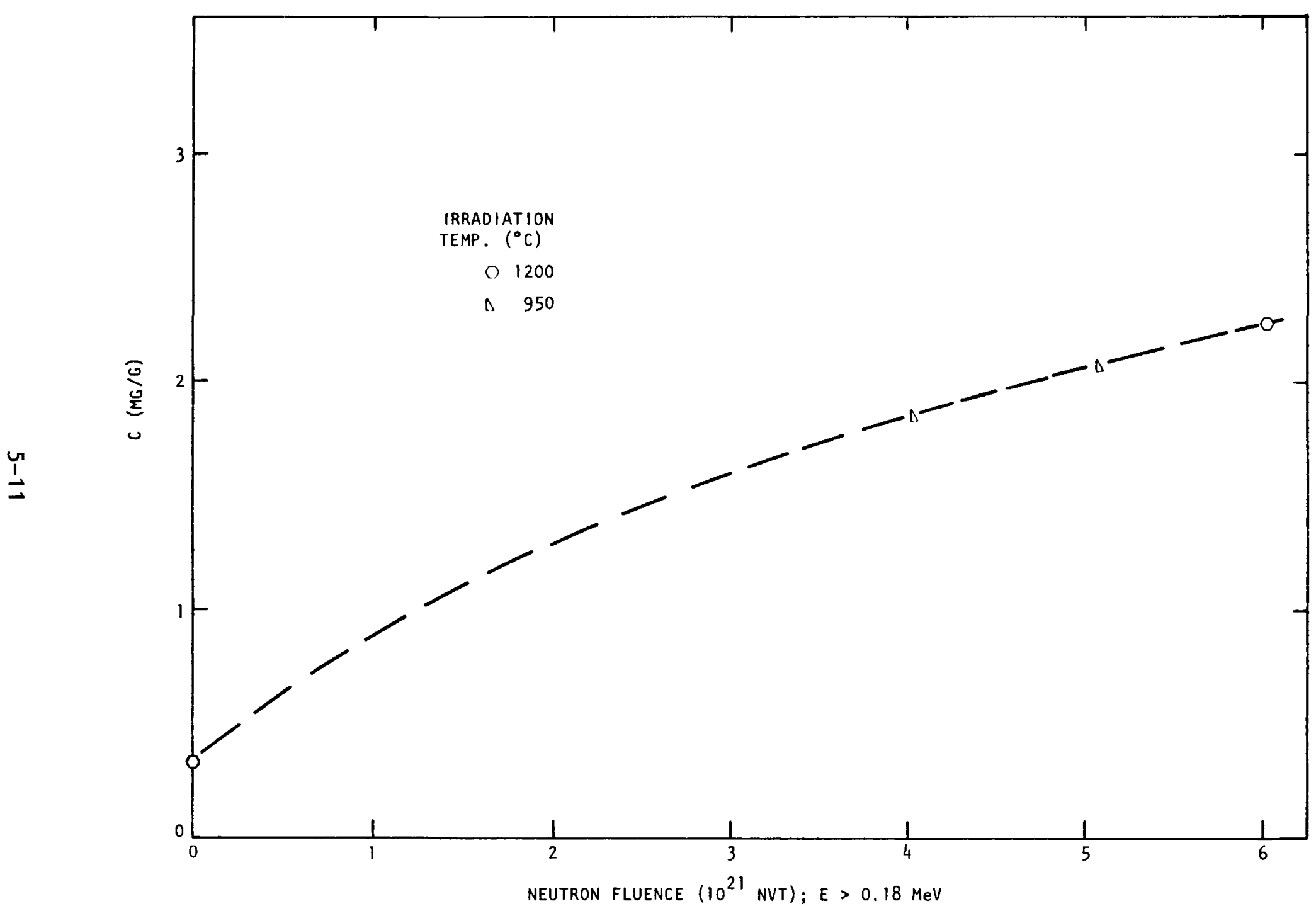

Fig. 5-4. Sorption of strontium on irradiated graphite at $1000^{\circ} \mathrm{C}, \mathrm{P}_{\mathrm{Sr}}=1.2 \times 10^{-6}$ atm 
one of the metals is sorbed. This can be qualitatively understood in terms of a set of sorption sites with various energies of metal binding. Norma11y, sites with higher binding energies are occupied by the sorbate species. With an additional species present, sites of lower binding energy are also occupied; this accounts for the relatively larger vapor pressure of one or both of the species. If the concentration of both sorbed metals is sufficiently small, as perhaps in the Henrian regime, the mixed isotope effect may not arise. Experiments have been conducted on cosorption of strontium with barium (Refs. 37-39) demonstrating a mixed isotope effect; however, further work is required on cosorption of strontium and barium before the experiments can provide a useful quantitative description. Furthermore, a satisfactory theoretical understanding of the mixed isotope effect has not been fully developed (Ref. 40).

\subsection{SELECTION OF REFERENCE DATA FOR SORPTION ON GRAPHITE}

On the basis of the isotherm data for strontium sorbed on graphite discussed in Section 5.3.1, values were selected for the constants A, B, $D$ and $E$ of Eqs. 5-1 and 5-3; the values are given in Table 3-1. The isotherm measurements were made on graphite type H-327. However, very recent measurements (Ref. 3) on the reference near-isotropic graphite, type $\mathrm{H}-451$, show no significant change in the characterization of the sorption isotherm. Thus, the data for $\mathrm{H}-327$ graphite are satisfactory for use in describing the sorption on the reference graphite over the concentration range of the experiments as indicated in Fig. 5-1. In the reference isotherms, the assumption of a transition to Henrian behavior at concentrations of sorbates below $0.12 \mu \mathrm{mole} / \mathrm{g}$ has been made on the basis of the Harwe11 data (Ref, 22). The transition concentration is assumed to be independent of temperature. The temperature independence has been shown to be valid at temperatures of 1500 and $1700^{\circ} \mathrm{K}$ (Ref. 22); at temperatures below $1500^{\circ} \mathrm{C}$ there are no data bearing on this assumption. In accordance with recent GA experiments (Ref. 27), no correction has been applied for a grain size effect in adapting the results from measurements on $37-74 \mu \mathrm{m}$ grains to bulk graphite as formulated for reactor use. 
On the basis of the constants given in Table 3-1 (A, B, D, and E) and of the assumption of a transition to Henrian behavior below $0.12 \mu \mathrm{mole} / \mathrm{g}$, isotherms for sorption of strontium on graphite have been drawn as in Fig. 3-6 by using Eqs. 5-1 and 5-3; at concentrations below the range of 0.1 to $1.0 \mu \mathrm{mole} / \mathrm{g}$ and temperatures below about $1300^{\circ} \mathrm{K}$, these isotherms are extrapolations.

\subsection{SORPTION ON FUEL ROD MATRIX}

Measurements of strontium sorption have been made for pitch-coke-based (Refs. 27, 41, 42) and resin-coke-based (Refs. 27, 41, 42, 43) fuel rod matrix materials. Results of experiments using pitch-coke-based materials are of primary interest in application to the HTGR since pitch-coke is used as the bonding material in fuel rods. A discussion of sorption on pitch-coke materials is given below.

The sorption measurements for strontium on pitch-cokes and matrices bonded with pitch-cokes are given in Table 5-1. These data are plotted in Fig. 5-5 (with the exception of one datum having $\phi=44,000$, which is clearly in error) for a temperature of $1500^{\circ} \mathrm{K}$. The reference isotherm at $1500^{\circ} \mathrm{K}$ for strontium sorbed on $\mathrm{H}-327$ graphite is also shown. The heats of vaporization of the cokes and graphite are similar for a given partial pressure and the relative positions of the isotherms remain virtually unchanged for other temperatures. Thus, values of $\phi$ are nearly independent of temperature; use is made of this relation in Fig. 5-5 to plot the data of Table 5-1 for the anneal and fuel test element (FTE) experiments.

The coke and matrix isotherms are approximately parallel. The calcined petroleum coke, carbonized at $2000^{\circ} \mathrm{C}$, yields a smaller value of $\phi$ than if carbonized at $1500^{\circ} \mathrm{C}$. This may reflect a structure which is dependent on the carbonizing temperature or a gettering effect of the sulfur impurity in the coke which is retained to a greater extent in the carbonizing process at the lower temperature. At carbonizing temperatures of 1500 and $2000^{\circ} \mathrm{C}$, the sulfur contents were $0.9 \%$ and $0.4 \%$, respectively. The values of $\phi$ for the Fort St. Vrain matrix material are a factor of two smaller than those 
TABLE 5-1

SORPTIVITY ON MATRIX MATERIAL FOR STRONTIUM RELATIVE TO H327 GRAPHITE

\begin{tabular}{|c|c|c|c|c|c|c|c|}
\hline Material $^{(a)}$ & $\begin{array}{c}\text { Type of } \\
\text { Material or } \\
\text { Binder (b) }\end{array}$ & $\mathrm{T}\left({ }^{\circ} \mathrm{C}\right)$ & $\begin{array}{c}\text { Matrix } \\
\text { Concentration } \\
(\mu \mathrm{mole} / \mathrm{g})\end{array}$ & $\emptyset$ & $\begin{array}{c}\text { Other } \\
\text { Metals } \\
\text { Present (c) }\end{array}$ & $\begin{array}{c}\text { Measure- } \\
\text { ment } \\
\text { Technique (d) }\end{array}$ & $\begin{array}{l}\text { Ref. } \\
\text { No. }\end{array}$ \\
\hline FSV matrix & c. pitch & 1400 & 7.0 & 36 & No & anneal & 27 \\
\hline$M-205$ & p. pitch & 1400 & 8.9 & 46 & No & anneal & 27 \\
\hline c.p.c. $(1500)$ & p. pitch & $1000-1530$ & Isotherm & 360 to 220 & No & m.s. & 41 \\
\hline c.p.c. (1500) & p. pitch & $1000-1530$ & Isotherm & 500 to 300 & No & m.s. & 41 \\
\hline c.p.c. $(2000)$ & p. pitch & $1000-1530$ & Isotherm & 180 to 10 & No & $\mathrm{m} \cdot \mathrm{s}$. & 41 \\
\hline FSV matrix & c. pitch & $1000-1530$ & Isotherm & 90 to 8 & No & $\mathrm{m} \cdot \mathrm{s}$. & 41 \\
\hline FSV matrix & c. pitch & $1000-1530$ & Isotherm & 75 to 5 & No & m.s. & 41 \\
\hline$c \cdot p \cdot c$. & p. pitch & 1057 & 16 & $620,44000^{(\mathrm{e})}$ & Yes & FTE & 42 \\
\hline$c \cdot p \cdot c$. & p. pitch & 963 & 16 & 177,958 & Yes & FTE & 42 \\
\hline
\end{tabular}

(a) FSV $=$ Fort St. Vrain, c.p.c. = calcined petroleum coke

(b) p. pitch = petroleum pitch, c. pitch = coal tar pitch

(c) Cesium, barium, or samarium were added to some FTE samples. The total concentration was generally no more than 2 or 3 times the strontium concentration.

${ }^{(d)}{ }_{\text {m.s. }}=$ mass spectrometer, FTE = Peach Bottom fuel test element diffusion sample. Carbonizing temperature was $1800^{\circ} \mathrm{C}$ unless indicated differently.

(e) This value is clearly in error. 


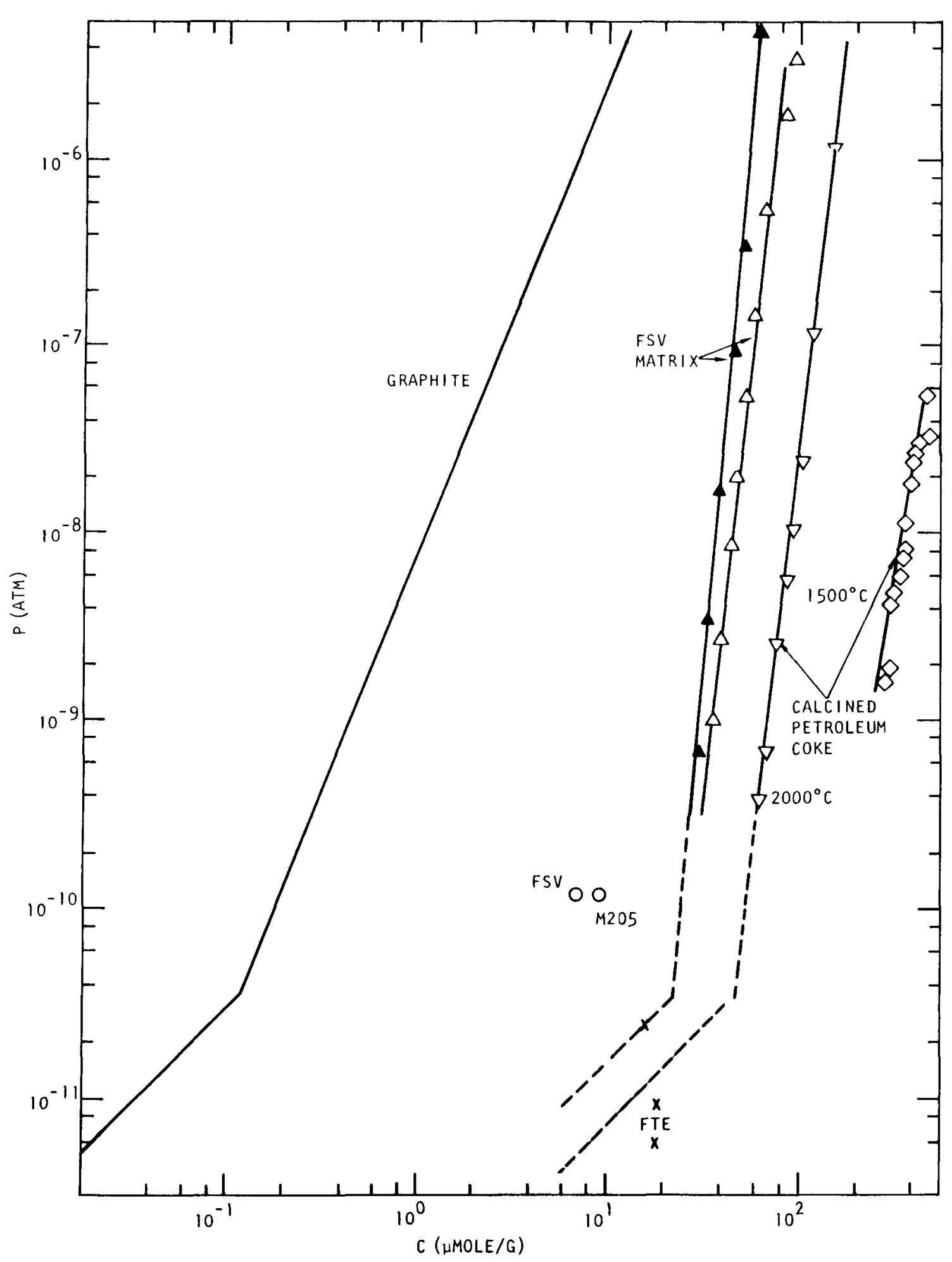

Fig. 5-5. Isotherms for strontium on fuel rod matrix and graphite at $1500^{\circ} \mathrm{K}$ 
for the petroleum coke calcined at $2000^{\circ} \mathrm{C}$ consistent with the composition of $40 \%$ coke residue in the former material. The binder coke in the Fort St. Vrain matrix is different from the calcined petroleum coke and could have properties contributing to the lower $\phi$ value. The Fort St. Vrain matrix material had an average sulfur content of only $0.07 \%$.

The fuel test element (FTE) data are for calcined petroleum cokes carbonized at $1800^{\circ} \mathrm{C}$ and clearly would not lie on extensions of a calcined petroleum coke isotherm for that temperature. If the isotherms for the calcined petroleum coke (as well as for the Fort St. Vrain matrix) are assumed to have a transition to a Henrian regime and at the same partial pressure as in the graphite isotherm, then the FTE data appear reasonably valued.

\subsection{SELECTION OF REFERENCE DATA FOR SORPTION ON FUEL ROD MATRIX}

The Fort St. Vrain matrix isotherms are taken as the reference isotherms; the isotherm parameters, based on measurements in the temperature range between 1300 and $1800^{\circ} \mathrm{K}$, are listed in Table $3-1$. The reference fuel rod matrix material is essentially the same as that for Fort St. Vrain; therefore, the reference isotherms for matrix material can be considered as representative of measurements on the reference material. In the reference isotherms, the assumption has been made of a transition to Henrian behavior at concentration of sorbates below $22.8 \mu$ mole/g of matrix material on the basis that the transition occurs at the same partial pressure as for the graphite isotherm. Furthermore, the transition concentration is assumed to be independent of temperature as was also assumed for sorption of strontium on graphite.

On the basis of the isotherm constants, A, B, D and E, as given in Table 3-1 and of the assumption of a transition to Henrian behavior below $22.8 \mu \mathrm{mole} / \mathrm{g}$, isotherms for sorption of strontium on fuel rod matrix material have been drawn as in Fig. 3-5 by using Eqs. 5-1 and 5-3; at concentrations below about $30 \mu \mathrm{mole} / \mathrm{g}$ and for temperatures below about $1300^{\circ} \mathrm{K}$, the isotherms are extrapolations. 


\section{DIFFUSION IN GRAPHIT'E WEB}

A large number of measurements of the diffusion coefficient of strontium in graphite have been made; these include concentration profile, permeation, and in-pile diffusion measurements. The agreement among these measurements is significantly improved when recognition is given to the dependence of the diffusion coefficient on the concentration of sorbed strontium for concentions in excess of about one umole of sorbed strontium per gram of graphite. For diffusion coefficients measured with strontium loadings below this limit, some scatter in the data remains which could involve a dependence on the type of graphite, but this is difficult to establish. Nevertheless, the diffusion coefficients for strontium loadings in the lower range of concentration are relatively well known.

\subsection{MEASUREMENT TECHNIQUES}

\subsubsection{Plane Source Diffusion Method}

Measurements of the diffusion coefficient of strontium are often performed using the plane source diffusion method. A source of tagged metal (such as graphite impregnated with Sr-85-tagged strontium) is sandwiched between two graphite specimens and annealed at desired temperatures. After the anneal, the graphite samples are sectioned perpendicular to the normal of the plane source and a concentration profile is obtained. The transient profile is analyzed using appropriate mathematical equations to obtain diffusion coefficients.

In a plot of the $\log$ of the concentration versus the square of the diffusion distance, a straight line of slope - 1/4Dt (where D is the diffusion coefficient and $t$ the diffusion time) is expected if the 
diffusion process conforms to Fick's law and if the diffusion coefficient is independent of concentration.

\subsubsection{Permeation Method}

This method involves (1) annealing a source material (such as charcoal impregnated with Sr-85-tagged strontium) in a graphite crucible, (2) measuring the evaporation rate of strontium from the crucible, and (3) determining strontium profiles across the crucible wall. Once the steady state evaporation rate (i.e., the $f l u x$ ) and the concentration profiles are known, a permeation coefficient can be calculated. Permeation experiments simulate fission product release from HTGR fuel elements more closely than other laboratory experiments. Permeation coefficients as derived from these experiments may be used to correctly calculate the permeation flux at steady state but can be inappropriate for calculating the delay time for diffusant to appear at the outer boundary. Thus, in experiments (Refs. 18, 20, 23, 28, $29,35,44-46)$ to measure the permeation of strontium in graphite, agreement between coefficients derived from steady state permeation fluxes and from delay times was obtained for experiments at high concentration in which high permeation rates were observed (the delay time $\tau$ is given by the ratio $\ell^{2} / 6 \mathrm{D}$ in which $\ell$ is the geometric length for diffusion and $\mathrm{D}$ is the diffusion coefficient). However, for experiments at low concentrations, the delay time calculated by using the permeation coefficient was orders of magnitude larger than observed. This apparent inconsistency was thought to arise from the existence of fast diffusivity paths which occupy only a small fraction of the cross-sectional area of the material in which diffusion occurs. The fraction of the cross-sectional area involved is given by the ratio of the permeation coefficient to the diffusion coefficient; this fraction had the approximate range of values $10^{-3}$ to $10^{-4}$ in the strontium permeation experiments.

\subsubsection{In-Pile Diffusion}

Diffusion coefficients have been derived from concentration profiles for strontium nuclides in graphite samples from capsule (irradiation) tests, 
from fuel test elements irradiated in reactor and loop facilities, and from driver elements (for example, Peach Bottom elements). This is an important source of diffusion coefficient data because the diffusion occurs under irradiation conditions.

Concentration profiles are obtained by sectioning the graphite samples and performing radiochemical analysis of the sections. Diffusion coefficients are obtained by fitting theoretical profiles to the measured profiles.

\subsubsection{Loss of Fission Products from Uranium-Loaded Graphite Samples}

In this technique, graphite cylindrical samples are impregnated with uranyl nitrate solution. Following impregnation, the samples are heated to convert the uranium from the nitrate to the oxide (or carbide) and then irradiated to produce fission products. Thus, the fission products are deposited directly in the graphite matrix. The samples are then annealed at desired temperatures and loss rates of metallic fission products are measured as a function of time. Sufficient time is allowed between the irradiation and the annealing for decay through fission product chains to members of interest. In analysis of the loss rate data to obtain diffusion coefficients, the assumption is normally made that diffusion is the ratelimiting process and that Fick's law applies. This technique was used successfully in early experiments by Bryant et al. (Ref. 47).

A reservation with this technique is that the fission product metals may be deposited directly within the crystallite grains and release from the grains might then be the rate limiting process in the experiments. However, in the experiments by Bryant et a1. (Ref. 47), the loss rate of strontium from the samples was not controlled by release from the crystallite grains. This conclusion was based on the observations that the loss rate from the samples was a function of the sample size and that concentration gradients were established by annealing. These data (Ref. 47) have been included in the present collation. The data from older experiments (Refs. 52, 53) of a similar nature have been compiled by Large (Ref. 54). 


\subsection{DIFFUSION COEFFICIENT DATA}

The collation of data on diffusion of strontium in graphite is presented in Table 6-1. These data are derived from measurements under a variety of conditions; these measurements are discussed below.

\subsubsection{Concentration Dependence of the Diffusion Coefficient}

By comparison of the data in Table 6-1, obtained under the condition of strontium loadings in excess of about one $\mu$ mole/g with those for smaller loadings, an indication of a dependence of the diffusion coefficient on the loading is obtained. A more incisive demonstration, however, is given by the data of Sandalls and Walford (Ref. 55) and of Besenbruch et a1. (Ref. 59). The latter investigators found more than a hundred-fold increase in the diffusion coefficient of strontium for a six-fold increase in source loading. The data of Sanda1ls and Walford, as shown in Fig. 6-1, demonstrate a dependence of the diffusion coefficient on the 3.15 th power of the concentration provided the concentration exceeds $62 \mu \mathrm{g} \mathrm{Sr} / \mathrm{g}(0.73 \mu \mathrm{mole} \mathrm{Sr} / \mathrm{g})$ for $1000^{\circ} \mathrm{C}$. The range of concentrations employed is nearly the same range as covered by the measurements collated in Table 6-1; in fact, there is qualitative agreement with the data of Table 6-1 as shown in Fig. 6-2 where diffusion coefficients are plotted against the loadings. (The solid line is a selected reference curve to be considered below.) This agreement indicates that concentration differences, i.e., in terms of loadings, are one of the prime factors to rationalize all the data. A theoretical treatment of the concentration dependence of the diffusion coefficient has been given by Zumwalt (Ref. 60); this treatment has been applied only to barium but the predicted dependence of the diffusion coefficient on the loading is qualitatively the same as shown in Fig. 6-2. 
TABLE 6-1

DIFFUSION COEFFICIENTS FOR STRONTIUM IN GRAPHITE

\begin{tabular}{|c|c|c|c|c|}
\hline Type of Graphite & $\begin{array}{l}\text { Temp } \\
\left({ }^{\circ} \mathrm{K}\right)\end{array}$ & $\mathrm{D}\left(\mathrm{cm}^{2} / \mathrm{sec}\right)$ & Comments & $\begin{array}{l}\text { Ref. } \\
\text { No. }\end{array}$ \\
\hline $\begin{array}{l}\text { HLM-85 impregnated (H) } \\
\text { HLM-85 base stock } \\
\text { GL-I-C6 } \\
\text { DH-3G } \\
\text { GL-I-S10 }\end{array}$ & $\begin{array}{l}1273 \\
1273 \\
1273 \\
1273 \\
1273\end{array}$ & $\begin{array}{l}1 \times 10^{-5} \\
1 \times 10^{-5} \\
4 \times 10^{-6} \\
8 \times 10^{-6} \\
3 \times 10^{-6}\end{array}$ & $\begin{array}{l}\text { Profiles } \\
\text { Saturation concentration } \\
1-10 \mu \mathrm{mole} / \mathrm{g}\end{array}$ & 48 \\
\hline Speer $711 \mathrm{TS}$ & 1273 & $\sim 5 \times 10^{-8}$ & $\begin{array}{l}\text { Profiles, initial loading } \\
10 \mu \mathrm{mole} / \mathrm{g}\end{array}$ & 49 \\
\hline Speer 711 TS or HLM-85 & 1273 & $1 \times 10^{-7}$ & Profiles & 50 \\
\hline Type A British reactor grade & $\begin{array}{r}1360 \\
1070 \\
770\end{array}$ & $\begin{array}{l}3.5 \times 10^{-6} \\
1.4 \times 10^{-6} \\
2.7 \times 10^{-7}\end{array}$ & $\begin{array}{l}\text { Profile analysis - approximately } \\
\text { confirmed by permeation } \\
\text { measurements }\end{array}$ & 51 \\
\hline EY-9 & $\begin{array}{r}1380 \\
1180 \\
1035 \\
1030 \\
970 \\
880\end{array}$ & $\begin{array}{l}1.5 \times 10^{-5} \\
7.9 \times 10^{-6} \\
2.5 \times 10^{-6} \\
2.7 \times 10^{-6} \\
1.9 \times 10^{-6} \\
1.1 \times 10^{-6}\end{array}$ & Loading $\sim 300 \mu \mathrm{mole} / \mathrm{g}$ & \\
\hline $\mathrm{HX}-10$ & $\begin{array}{r}1380 \\
1180 \\
770\end{array}$ & $\begin{array}{l}1.3 \times 10^{-5} \\
7.7 \times 10^{-6} \\
9.6 \times 10^{-7}\end{array}$ & & \\
\hline $\mathrm{HX}-12$ & $\begin{array}{r}1370 \\
1180 \\
990 \\
990 \\
830\end{array}$ & $\begin{array}{l}6.9 \times 10^{-6} \\
5.7 \times 10^{-6} \\
7.1 \times 10^{-7} \\
9.6 \times 10^{-7} \\
4.4 \times 10^{-7}\end{array}$ & & \\
\hline
\end{tabular}


TABLE 6-1 (Continued)

\begin{tabular}{|c|c|c|c|c|}
\hline Type of Graphite & $\begin{array}{l}\text { Temp } \\
\left({ }^{\circ} \mathrm{K}\right)\end{array}$ & $\mathrm{D}\left(\mathrm{cm}^{2} / \mathrm{sec}\right)$ & Comments & $\begin{array}{l}\operatorname{Ref} . \\
\text { No. }\end{array}$ \\
\hline AUF & $\begin{array}{l}1973 \\
1873 \\
1773 \\
1073 \\
\end{array}$ & $\begin{array}{r}1.5 \times 10^{-4} \\
8 \times 10^{-5} \\
4 \times 10^{-5} \\
3.8 \times 10^{-9} \\
\end{array}$ & Calculated from Refs. 52, 53 & 54 \\
\hline A.G.L. 9 & $\begin{array}{l}1860 \\
1690 \\
1610 \\
1480\end{array}$ & $\begin{array}{l}3.0 \times 10^{-6} \\
4.0 \times 10^{-7} \\
1.5 \times 10^{-7} \\
1.1 \times 10^{-8}\end{array}$ & $\begin{array}{l}\text { Profiles } \\
\mathrm{C}<0.7 \text { Hmole/g }\end{array}$ & 55 \\
\hline A.G.L. 9 & $\begin{array}{l}1100 \\
1333\end{array}$ & $\begin{array}{l}2.0 \times 10^{-6} \\
1.8 \times 10^{-5}\end{array}$ & $\mathrm{C}=20 \mu \mathrm{mole} / \mathrm{g}$ & \\
\hline Bar 67 & $\begin{array}{l}1860 \\
1750 \\
1655 \\
1580 \\
1485\end{array}$ & $\begin{array}{l}6.9 \times 10^{-6} \\
2.1 \times 10^{-6} \\
7.7 \times 10^{-7} \\
1.9 \times 10^{-7} \\
3.7 \times 10^{-8}\end{array}$ & $c<0.7 \mu$ mole $/ g$ & \\
\hline "Bar 16" & 1590 & $1.1 \times 10^{-7}$ & & \\
\hline British Acheson pitchcoke & 1575 & $1.6 \times 10^{-7}$ & & \\
\hline Spec pure & 1610 & $3.0 \times 10^{-7}$ & & \\
\hline Dragon fuel tube ( $\mathrm{HX} 30)$ & $\begin{array}{l}1150 \\
1220\end{array}$ & $\begin{array}{lll}5 & \times 10^{-12} \\
5 & \times 10^{-12}\end{array}$ & Profiles & 55 \\
\hline
\end{tabular}


TABLE 6-1 (Continued)

\begin{tabular}{|c|c|c|c|c|}
\hline Type of Graphite & $\begin{array}{l}\text { Temp } \\
\left({ }^{\circ} \mathrm{K}\right)\end{array}$ & $\mathrm{D}\left(\mathrm{cm}^{2} / \mathrm{sec}\right)$ & Comments & $\begin{array}{l}\text { Ref. } \\
\text { No. }\end{array}$ \\
\hline H327 graphite (FTEs) "bulk" & $\begin{array}{l}1055 \\
1250 \\
1250 \\
1113 \\
1113 \\
1241 \\
1241 \\
1230 \\
1230\end{array}$ & $\begin{array}{l}4.6 \times 10^{-12} \\
8.2 \times 10^{-10} \\
1.1 \times 10^{-9} \\
8.1 \times 10^{-11} \\
6.3 \times 10^{-11} \\
2.9 \times 10^{-10} \\
2.5 \times 10^{-10} \\
4.1 \times 10^{-9} \\
1.6 \times 10^{-9}\end{array}$ & $\begin{array}{l}\text { Profiles } \\
\mathrm{C} \approx 0.2 \text { to } 1.4 \mu \mathrm{mole} / \mathrm{g}\end{array}$ & 42 \\
\hline $\begin{array}{l}\text { CXY-165 double furfury } 1 \\
\text { impregnated graphite }\end{array}$ & $\begin{array}{l}1026 \\
1026 \\
1121 \\
1196\end{array}$ & $\begin{array}{l}3.7 \times 10^{-8} \\
5.1 \times 10^{-8} \\
2.4 \times 10^{-7} \\
4.4 \times 10^{-7}\end{array}$ & $\begin{array}{l}\text { Profiles } \\
\text { Loading }>600 \mu \mathrm{mole} / \mathrm{g}\end{array}$ & 56 \\
\hline $\begin{array}{l}\text { Self-made admixed and graphi- } \\
\text { tized ( } \mathrm{UO}_{2}+\mathrm{C}+\text { binder) or } \\
\mathrm{U} \text { impregnated AUC graphite }\end{array}$ & $\begin{array}{l}1823 \\
2198 \\
2473\end{array}$ & $\begin{array}{l}2.8 \times 10^{-6} \\
6.6 \times 10^{-5} \\
2.0 \times 10^{-4}\end{array}$ & $\begin{array}{l}\text { Release rate of recoils from } \\
\text { impregnated cylinders. Loading } \\
<10^{-5} \mu \text { mole/g }\end{array}$ & 47 \\
\hline Pluto loop fuel tubes & $\begin{array}{l}1173 \\
1273 \\
1393 \\
1333 \\
1673 \\
1743\end{array}$ & $\begin{array}{l}2 \times 10^{-10} \\
1 \times 10^{-9} \\
2 \times 10^{-8} \\
1 \times 10^{-10} \\
2 \times 10^{-8} \\
2 \times 10^{-8}\end{array}$ & $\begin{array}{l}\text { D calculated from steep part } \\
\text { of concentration profile. } \\
\text { Loading } \sim 0.1 \mu \text { mole } / g\end{array}$ & 57 \\
\hline
\end{tabular}


TABLE 6-1 (Continued)

\begin{tabular}{|c|c|c|c|c|}
\hline Type of Graphite & $\begin{array}{l}\text { Temp } \\
\left({ }^{\circ} \mathrm{K}\right)\end{array}$ & $D\left(\mathrm{~cm}^{2} / \mathrm{sec}\right)$ & Comments & $\begin{array}{l}\text { Ref. } \\
\text { No. }\end{array}$ \\
\hline H327 Graphite & $\begin{array}{l}1248 \\
1248 \\
1273 \\
\\
1273 \\
1273\end{array}$ & $\begin{array}{r}4.7 \times 10^{-7} \\
4.3 \times 10^{-7} \\
2.4 \times 10^{-9} \\
\\
1 \times 10^{-10} \\
3 \times 10^{-11} \\
\end{array}$ & $\begin{array}{l}\text { Permeation (in helium) } \\
\text { C } \sim 4 \mu \mathrm{mole} / \mathrm{g} \\
\mathrm{C} \sim 3.4 \mu \mathrm{mole} / \mathrm{g} \\
\mathrm{C} \sim 0.08 \mu \mathrm{mole} / \mathrm{g} \\
\text { Permeation (in vacuum) } \\
\text { C } \sim 0.2 \mu \mathrm{mole} / \mathrm{g} \\
\mathrm{C} \sim 0.045 \mu \mathrm{mole} / \mathrm{g}\end{array}$ & 2844 \\
\hline Pechiney $\mathrm{P}_{3}$ JHAN & $\begin{array}{l}1373 \\
1423 \\
1463 \\
1573 \\
1673 \\
1773 \\
1883 \\
\end{array}$ & $\begin{array}{l}4.15 \times 10^{-9} \\
2.56 \times 10^{-8} \\
6.34 \times 10^{-8} \\
3.16 \times 10^{-7} \\
9.29 \times 10^{-7} \\
3.17 \times 10^{-6} \\
5.70 \times 10^{-6} \\
\end{array}$ & $\begin{array}{l}\text { Profile analysis } \\
\mathrm{C} \leq 0.01 \mu \mathrm{mole} / \mathrm{g}\end{array}$ & 58 \\
\hline Pechiney $\mathrm{P}_{3}$ JHAN & $\begin{array}{l}1373 \\
1423 \\
1463 \\
1573 \\
1673 \\
1773 \\
1883\end{array}$ & $\begin{array}{l}3.5 \times 10^{-9} \\
5.2 \times 10^{-8} \\
8.2 \times 10^{-8} \\
5.4 \times 10^{-7} \\
1.2 \times 10^{-6} \\
1.7 \times 10^{-6} \\
8.1 \times 10^{-6}\end{array}$ & $\begin{array}{l}\text { Activity change in source } \\
C \leq 0.01 \mu \mathrm{mole} / \mathrm{g}\end{array}$ & 58 \\
\hline
\end{tabular}




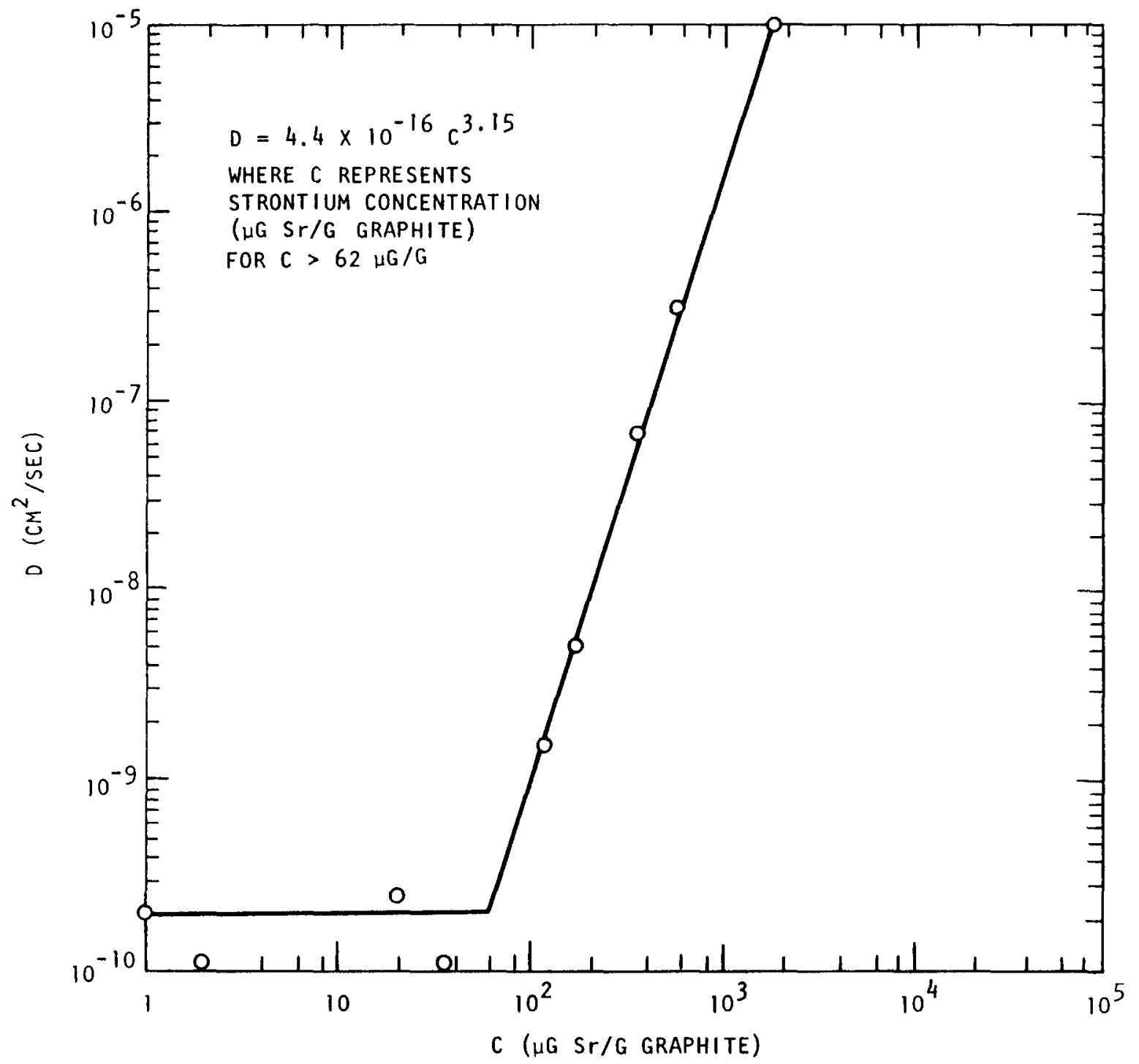

Fig. 6-1. Variation of the diffusion coefficient with concentration of strontium in A.G.L. 9 graphite at $1000^{\circ} \mathrm{C}$ 


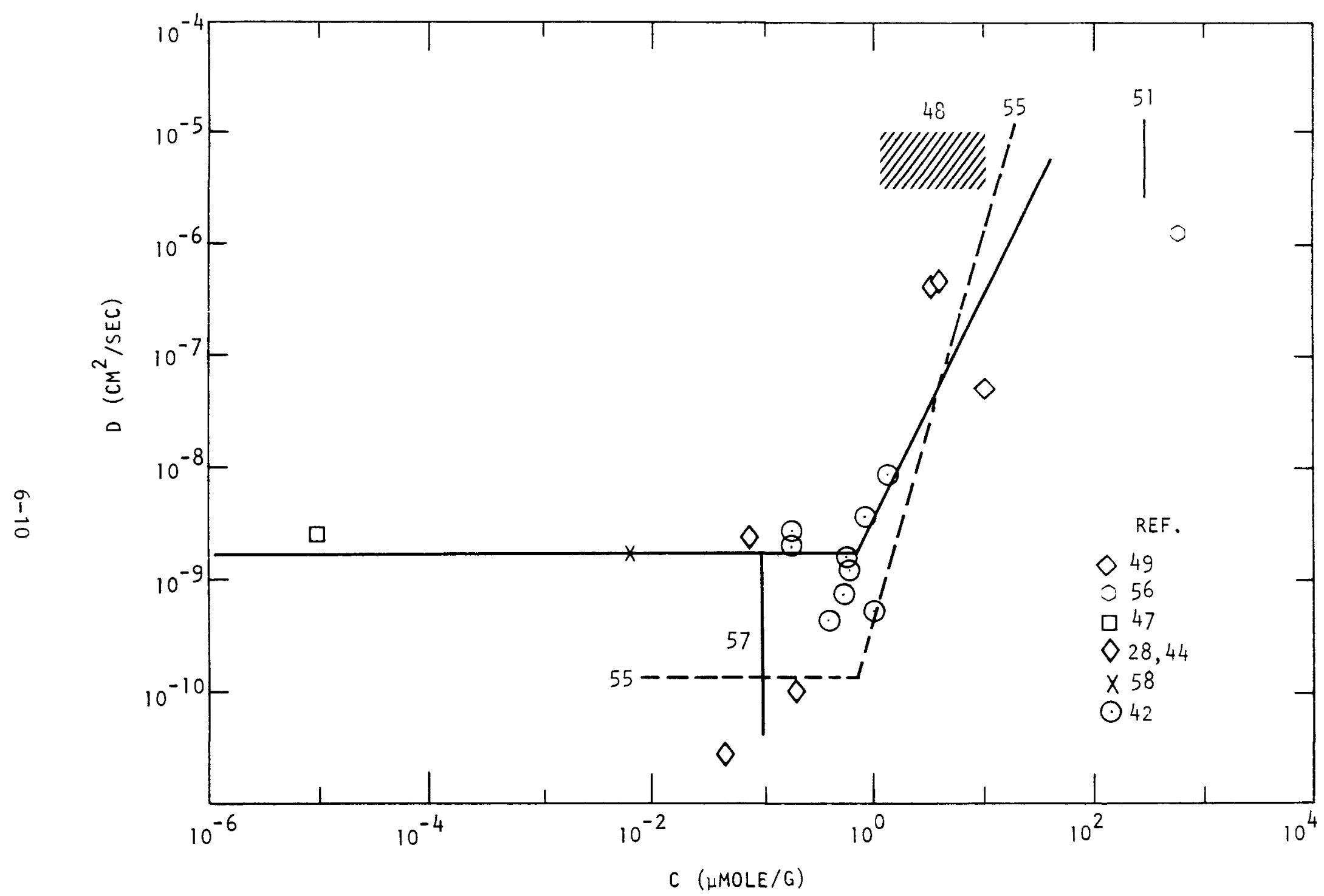

Fig. 6-2. Concentration dependence of the diffusion coefficient for strontium in graphite at $1000^{\circ} \mathrm{C}$ 
In the systematic study (Ref. 55) of the concentration dependence of diffusion coefficients, temperature coefficients for diffusion were also obtained. The temperature coefficient for diffusion of strontium in graphite genera11y decreased with increase in concentration. A monotonic decrease was indicated only for source loadings in excess of about 1.4 $\mu$ mole/g; the temperature coefficient decreased from the range 80 to 100 $\mathrm{kcal} / \mathrm{mole}$ to $27 \mathrm{kcal} / \mathrm{mole}$ at a loading of $20 \mu \mathrm{mole} / \mathrm{g}$. Again, there is a qualitative agreement with the data of Table 6-1.

\subsubsection{The Mixed Isotope Effect}

In addition to the effect of large concentrations of strontium on the diffusion coefficient, there is evidence suggesting that other sorbed species have similar effects; thus calcium preloaded onto graphite samples had about the same effect as preloaded strontium (Ref. 55). Also, from analysis of fuel test elements taken from the Peach Bottom HTGR, the conclusion was reached (Ref. 42) that the diffusion coefficient of strontium was increased by the presence of other diffusants. Further analysis of the strontium data indicates that at least barium and cesium are effective in increasing the diffusion coefficient of strontium.

\subsubsection{Penetration Profiles of Diffusant}

The concentration of the diffusant as a function of penetration distance in the graphite has been measured by several groups over a range of concentrations. In the range between $1 \mu \mathrm{g} \mathrm{Sr} / \mathrm{g}$ and $2 \mathrm{mg} \mathrm{Sr} / \mathrm{g}$, no deviation was reported (Refs. 55, 58) from the expected dependence of the logarithm of the concentration of strontium on the square of the penetration distance. Furthermore, no remarkable difference was found (Ref. 55) among experiments in which several types of graphite having a range of BET surface areas between 0.13 and $1.1 \mathrm{~m}^{2} / \mathrm{g}$ were used. Some older experiments (Refs. 26, 59) yielded concentration profiles which are in contrast to the above results for loadings less than $2 \mathrm{mg}$ strontium per gram of graphite. In these experiments, profiles were obtained which have an initial steep decrease 
in concentration with increasing penetration into the graphite followed by a low-concentration tail. The conventional explanation attributes the curved concentration profile to the operation of two transport processes: a slow diffusion process, possibly in the bulk of the material and representing the steep, initial decline in the concentration profile, and a fast diffusion process, perhaps a surface or grain boundary diffusion.

The weight of the evidence favors the view that concentration profiles for a plane source will be found to show a linear relation between the logarithm of the concentration of diffusant and the square of the penetration distance, at least for smaller loadings in the case of strontium diffusion in graphite. However, the possibility of a dependence of the form of the concentration profile on the concentration of sorbed species for larger concentrations and a1so on temperature should be retained until experimental evidence indicates otherwise.

Many of the diffusion coefficients of Table 6-1 have been derived from concentration profile analyses. In three sets of data (Refs. 42, 55, 58), the concentrations of sorbed strontium are in the range of interest for HTGR applications while for the remainder of the data using profile analysis, the concentrations are in excess of those of interest. In the lowconcentration studies (Refs. 42, 55, 58), the classical description of diffusion by Fick's law has been found to apply to the data.

In-pile derived diffusion coefficients of Table 6-1 were obtained from the Pluto Loop (Ref. 57) and Dragon Reactor (Ref. 55) fuel tubes. In the former case, radial temperature variations of about $100^{\circ} \mathrm{C}$ in the fuel tube were not taken into consideration resulting in an overestimate of the diffusion coefficient. Also, the concentration profiles had tails which were ignored. 
Additional diffusion experiments were performed (Ref. 42) using meta1impregnated sources which were inserted in the Peach Bottom reactor. Concentration profiles were analyzed, and for strontium they were generally of the Fickian form, as mentioned above. The concentrations of strontium were small but there was an indication of a concentration dependence of the diffusion coefficients when the total concentration of all elements was considered.

6.3. SELECTION OF REFERENCE DATA FOR DIFFUSION OF STRONTIUM IN GRAPHITE

For concentrations of sorbed strontium below approximately one $\mu$ mole per gram of graphite, experimental evidence (Ref. 55) indicates no dependence of the diffusion coefficient on the concentration. A11 the data of Table 6-1 for which the experimental concentrations are known to be less than approximately one $\mu$ mole/g are plotted in Fig. 6-3. The solid curve is the selected reference curve for these data; in the selection of this curve, the fuel test element (FTE) data (Ref. 42) at the lower temperatures have been weighted heavily. The parameters for the reference curve of Fig. 6-3 are given in Table 3-1; the reference curve is shown also in Fig. $3-4$.

The data of Fig. 6-3 represent measurements in which a variety of graphites have been used (Table 6-1). However, there is no evidence for a strong dependence of the diffusion coefficient on the type of graphite. While the data were not obtained by using the reference isotropic graphite, measurements in which the isotropic graphite is used can be reasonably expected to yield diffusion coefficients not significantly different from those shown in Fig. 6-3. 


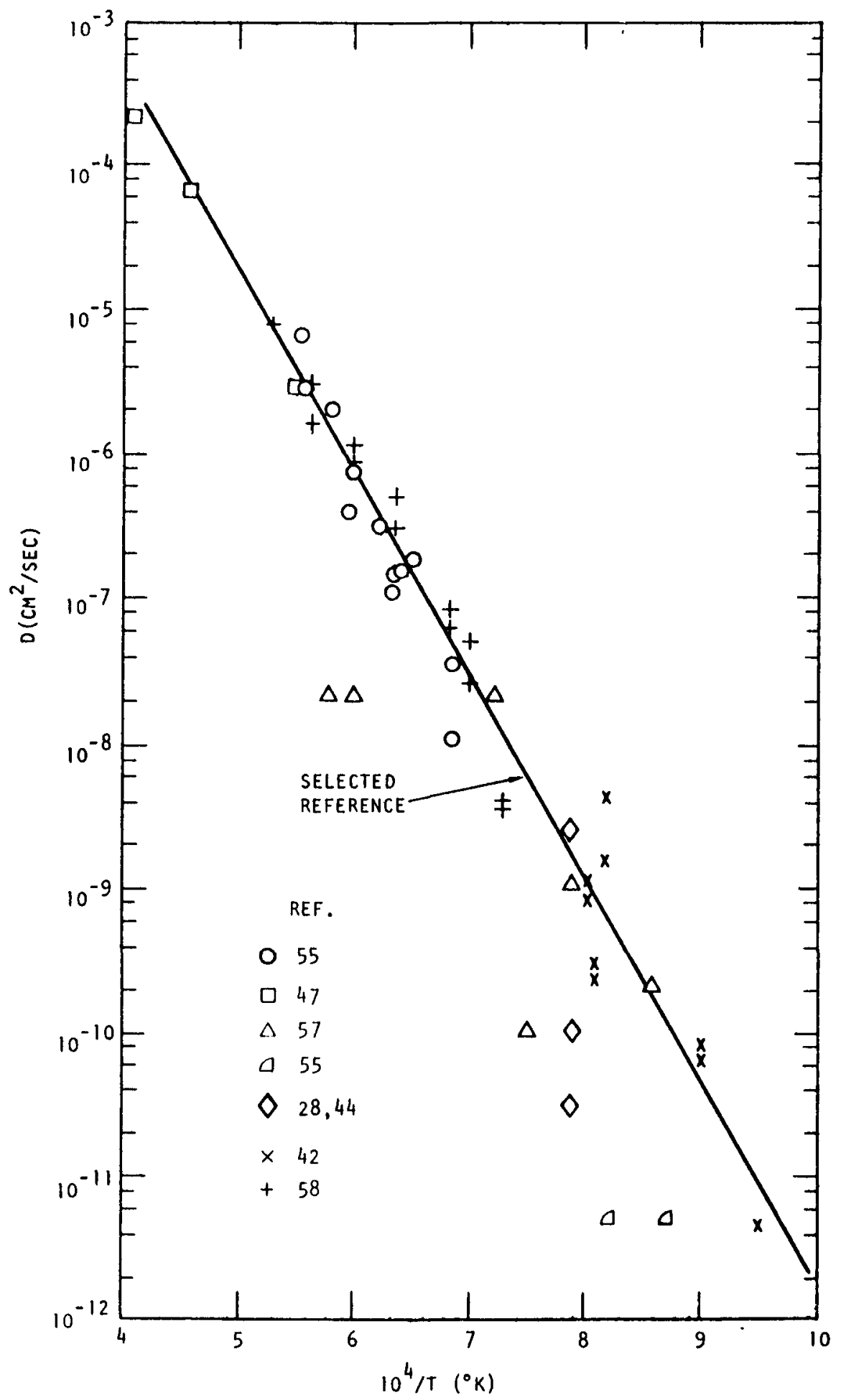

Fig. 6-3. Strontium diffusion coefficients in graphite 
A concentration dependence for strontium diffusion in graphite has been established. This is shown in Fig. $6-2$ at $1000^{\circ} \mathrm{C}$ for the data of Table 6-1. The selected reference curve in Fig. 6-2 is given by the heavy line; the change in slope to a value of two occurs at a concentration of about 0.7 umole/g of strontium in graphite. At other temperatures the slope of the line (for concentrations greater than $0.7 \mu \mathrm{mole} / \mathrm{g}$ ) will change, becoming smaller at higher temperatures. Based on the observations of the concentration dependence of the diffusion coefficient and the temperature coefficient as well, empirical expressions can be derived which describe these variations in the concentration interval studied. One such empirical expression, which is based on the relationship of Fig. 6-2 and on the variation of the temperature coefficient with concentration, is the following:

$$
D=3.47 \times 10^{-9} C^{2} \exp \left[-\frac{64000 \times}{R}\left\{\frac{1}{T}-\frac{1}{1273}\right\}\right]
$$

where $\mathrm{C}=$ concentration of strontium in $\mu \mathrm{mole} / \mathrm{g}$ and

$$
x=0.422+0.5805\left[1+\frac{c^{3}}{80}\right]^{-1}
$$

In obtaining Eqs. 6-1 and 6-2, the value of $Q$, the temperature coefficient (or activation energy) of Eq. 3-1, was taken as 64,000 cal/mole for $\mathrm{C}=0.7 \mu \mathrm{mole} / \mathrm{g}$ and as $27,000 \mathrm{cal} / \mathrm{mole}$ at very large concentrations. The former limit corresponds to the temperature coefficient derived from the reference line in Fig. 6-3 and the latter limit is roughly equal to the smallest observed value in systematic studies (Ref. 55). Eqs. 6-1 and 6-2 apply for the conditions that $0.7 \mu \mathrm{mole} / \mathrm{g}<\mathrm{C} \leq 50 \mu \mathrm{mole} / \mathrm{g}$. These expressions are suitable only for estimation purposes since they are based on limited data. Also, the diffusion coefficient of Eq. 6-1 may represent a composite of transport processes in which the dominate process may depend on the concentration. 


\section{ACKNOWLEDGEMENT}

This report was based on a collation and preliminary review of much of the data by L. H. Rovner.

$7-1$ 


\section{REFERENCES}

1. Haire, M. J., and D. W. McEachern, "Gaseous Radioactivity Levels in the Primary Coolant of an HTGR," General Atomic Report GA-A12946 (GA-LTR-14), October 1, 1974.

2. Forutanpour, B., and B. Roos, "FIPER, A Fortran IV Program for the Solution of One Dimensional Linear and Non-Linear Diffusion Problems," Gulf GA-9904, Gulf General Atomic, September 1969.

3. "HTGR Base Program Quarterly Progress Report for the Period Ending November 19, 1974," General Atomic Company, to be published.

4. Nabiclok, H., et a1., "Performance Limits of Coated Particle Fue1, Part III, Fission Product Migration in HT.R Fuel," DP Report 828 (Pt 3), AEE Winfrith, Dorchester, Dorset, England, June 1974.

5. Harmon, D. P., "Summary Compilation of Gulf General Atomic Coated Particle Irradiation Experiments," USAEC Report GAMD-9245, Gulf General Atomic, October 1973.

6. "Public Service Company of Colorado 330-MW(e) High Temperature Gas Cooled Reactor Research and Development Program, Quarterly Progress Report for the Period Ending September 30, 1966," USAEC Report GA-7453, General Atomic, February 7, 1967.

7. "Public Service Company of Colorado 330-MW(e) High Temperature Gas Cooled Reactor Research and Development F'rogram, Quarterly Progress Report for the Period Ending June 30, 1966," USAEC Report GA-7314, General Atomic, September 30, 1966.

8. "Public Service Company of Colorado 330-MW(e) High Temperature Gas Cooled Reactor Research and Development Program, Quarterly Progress Report for the Period Ending March 31, 1966," USAEC Report GA-7086, Genera1 Atomic, May 11, 1966.

9. Zumwalt, L. R., P. E. Gethard, and E. E. Anderson, "Fission-Product Release from Monogranular UC 2 Particles," Nuc. Sci. Eng. 21, 1 (1965). 
10. "Public Service Company of Colorado 330-MW(e) High Temperature Gas Cooled Reactor Research and Development Program, Quarterly Progress Report for the Period Ending September 30, 1965," USAEC Report GA-6830, General Atomic, December 31, 1965.

11. Beck, S. D., "The Diffusion of Radioactive Fission Products From Porous Fue1 Elements," Batte1le Memorial Institute Report No. BMI-1433, April 18, 1960.

12. Flowers, R. H., "Fission Product Control in the HTR," Atomic Energy Research Establishment, AERE-R-7493, Harwe11, Berkshire, 1973.

13. Morgan, M. T., R. L. Towns, and L. L. Fairchild, "Fission Product Transport Through Particle Coatings," Gas-Cooled Reactor and Thorium Utilization Programs, Annual Progress Report for Period Ending September 30, 1971, ORNL-4760, Oak Ridge Nationa1 Laboratory, January 1973.

14. Gethard, P. E., and L. R. Zumwalt, "Diffusion of Metallic Fission Products in Pyrolytic Carbon," Nuc1. App1. $\underline{3}, 679$ (1967).

15. Freundlich, H., Trans. Faraday Soc. 28, 195 (1932).

16. Milstead, C. E., A. B. Riedinger, and L. R. Zumwalt, "Cesium-Graphite Sorption Isotherms Determined by a Static Method," Carbon 4, 99-106 (1966).

17. "HTGR Base Program Quarterly Progress Report for the Period Ending August 31, 1973," USAEC Report GA-A12725, Gulf General Atomic, September 28, 1973.

18. "HTGR Base Program Quarterly Progress Report for the Period Ending November 30, 1970," USAEC Report GA-10399, Gulf General Atomic, December 31, 1970.

19. "HTGR Base Program Quarterly Progress Report for the Period Ending May 31, 1973," USAEC Report Gulf-GA-A12599, Gulf General Atomic, June $29,1973$.

20. "HTGR Base Program Quarterly Progress Report for the Period Ending May 31, 1971," USAEC Report Gulf-GA-10661, Gulf General Atomic, June 30, 1971 .

21. "HTGR Base Program Quarterly Progress Report for the Period Ending February 28, 1967," USAEC Report GA-7801, Genera1 Dynamics, Genera1 Atomic Division, Apri1 20, 1967. 
22. Faircloth, R. L., and C. D. Crossley, "The Adsorption Isotherm of Strontium on H-327 Graphite," AERE Harwell; letter from R. H. Flowers to W. E. Bell, October 14, 1970.

23. "HTGR Base Program Quarterly Progress Report for the Period Ending May 30, 1969," USAEC Report GA-9372, Gulf General Atomic, June 27, 1969.

24. Flowers, R. H., J. B. Sayers, and M. S. T. Price, "Safety Aspects of High Temperature Reactor Systems," paper 16, Session IV, OECD High Temperature Reactor Project (Dragon) Colloquium, Paris, November 24-25, 1971.

25. "HTGR Base Program Quarterly Progress Report for the Period Ending November 30, 1967," USAEC Report GA-8356, Gulf Genera1 Atomic, December 29, 1967.

26. "HTGR Base Program Quarterly Progress Report for the Period Ending February 29, 1968," USAEC Report GA-8530, Gulf Genera1 Atomic, March 29, 1968.

27. "HTGR Base Program Quarterly Progress Report for the Period Ending February 28, 1974," USAEC Report GA-A12916, Gulf General Atomic, March 29, 1974.

28. "HTGR Base Program Quarterly Progress Report for the Period Ending February 28, 1969," USAEC Report GA-9227, Gulf General Atomic, March 28, 1969.

29. "HTGR Base Program Quarterly Progress Report for the Period Ending February 28, 1971," USAEC Report GA-10501, Gulf General Atomic, March 30, 1971.

30. "HTGR Base Program Quarterly Progress Report for the Period Ending May 31, 1967," USAEC Report GA-7981, General Dynamics, Genera1 Atomic Division, September 29, 1967.

31. "HTGR Base Program Quarterly Progress Report for the Period Ending August 31, 1970," USAEC Report GA-10288, Gulf General Atomic, September 30, 1970.

32. Flowers, R. H., and E. G. Rauk, "Studies of the Equilibrium Vapor Pressure Over the Alkaline Earth Carbides," J. Inorg. Nuc1. Chem 28, 1355-1366 (1966).

33. Cuthbert, J., et al., "Vaporization of Alkaline-Earth and Rare-Earth Metal Dicarbides," Proc. Brit. Ceram Soc 8, 155-173 (1967). 
34. "HTGR Base Program Quarterly Progress Report for the Period Ending November 30, 1969," USAEC Report GA-9815, Gulf General Atomic, December 30, 1969.

35. "HTGR Base Program Quarterly Progress Report for the Period Ending May 31, 1968," USAEC Report GA-8662, Gulf General Atomic, June 28, 1968.

36. Milstead, C. E., "Effects of Irradiation on the Cesium Sorption Characteristics of Graphite," Gulf General Atomic Report GA-8589, April 19, 1968.

37. "Public Service Company of Colorado 330 MW(e) High-Temperature GasCooled Reactor Research and Development Program, Quarterly Progress Report for the Period Ending September 30, 1966," USAEC Report GA-7453, General Dynamics, General Atomic Division, February 7, 1967.

38. "Public Service Company of Colorado 330 MW(e) High Temperature GasCooled Reactor Research and Development Program, Quarterly Progress Report for the Period Ending December 31, 1966," USAEC Report GA-7634, General Dynamics, General Atomic Division, March 20, 1967.

39. Norman, J. H., L. R. Zumwa1t, and H. G. Staley, "Thermodynamics of Adsorption of Mixed Metallic Elements on Graphite at High Temperature," Report GA-7968, Genera1 Dynamics, General Atomic Division, May 5, 1967.

40. Haire, M. J. and L. R. Zumwalt, "Mixed Sorption Models and Isotherms of the Cesium-Rubidium-Graphite System at High Temperatures," Nuc1. Sci. Eng. 50, 91-97 (1973).

41. "Public Service Company of Colorado 330 MW(e) High Temperature GasCooled Reactor Research and Development Program Quarterly Progress Report for the Period Ending March 31, 1970," USAEC Report GA-10010, General Atomic, April 30, 1970.

42. Zumwalt, L. R., et al., "Fue1 Test Element No. 3 Postirradiation Examination," General Atomic Report GA-A13004, August 15, 1974.

43. "Public Service Company of Colorado 330 MW(e) High Temperature GasCooled Reactor Research and Development Program Quarterly Report for the Period Ending June 30, 1968," USAEC Report GA-8725, Gulf Genera1 Atomic, Ju1y 29, 1968.

44. "HTGR Base Program Quarterly Progress Report for the Period Ending August 31, 1969," USAEC Report GA-9660, Gulf General Atomic, September $25,1969$. 
45. "HTGR Base Program Quarterly Progress Report for the Period Ending February 28, 1970," USAEC Report GA-9944, Gulf General Atomic, March 31, 1970.

46. "HTGR Base Program Quarterly Progress Report for the Period Ending May 31, 1970," USAEC Report GA-10088, Gulf General Atomic, June $30,1970$.

47. Bryant, E. A., et a1., "Rates and Mechanisms of the Loss of Fission Products from Uranium-Graphite Fue1 Materia1s," Nuc1. Sci. Eng 15, 288-295 (1963).

48. "HTGR Chemistry Quarterly Progress Report for the Period OctoberDecember 1961," General Dynamics/General Atomic Division, January 11, 1962.

49. "ESADA Chemistry Quarterly Report, July-September, 1963," General Dynamics/General Atomic Division, October 28, 1963.

50. "TARGET A Program for a 1000-MW(e) High Temperature Gas-Cooled Reactor, Quarterly Progress Report for the Period Ending February 29, 1964," USAEC Report GA-5104, General Dynamics, General Atomic Division, February 29, 1964.

51. Bromley, J., A. R. Paddon, and K. Moul, "The Diffușion of Cesium, Strontium and Barium Through Porous Graphites," AERE Report-R3471, Atomic Energy Research Establishment, Harwe11, 1962.

52. Doyle, L. B., Report N.A.A.-SR-225, North American Aviation, Inc. 1952.

53. Young, C. T., "High Temperature Diffusion of Individual Fission Products From Small Uranium Impregnated Graphite Samples Under Deuteron Bombardment," Report N.A.A.-SR-247, North American Aviation, Inc., May $28,1953$.

54. Large, N. R., Report AERE C/M-318, Atomic Energy Research Establishment, Harwe11, Berkshire, 1957. 
55. Sandalls, F. J., and M. R. Walford, "Laboratory Determinations of Strontium Diffusion Coefficients in Graphite," Report AERE R-6911, Atomic Energy Research Establishment, Harwe11, Berkshire, 1972.

56. Faircloth, R. L., F. C. W. Pummery, and B. A. Rolls, "Diffusion of Barium, Strontium and Cerium in Various Grades of Reactor Graphite," Thermodynamics: Proceedings of the Symposium on Thermodynamics with Emphasis on Nuclear Materials and Atomic Transport in Solids II 133-152, International Atomic Energy Agency, Vienna, 1966.

57. de Nordwa11, H. J., et a1., "Post Irradiation Radiochemical Analysis of Pluto Loop A Charge 16," Report AERE-R-5405, Atomic Energy Research Establishment, Harwe11, Berkshire, June 1967.

58. Absassin, J. J., R. J. Blanchard, and J. Carriot, "Determination Des Coefficients De Diffusion Du Strontium Dans Le Graphite $\mathrm{P}_{3}$ JHAN, En Function De La Temperature," Compte Reader DMG $N^{\circ} \operatorname{Dr} 11 / 74$, C.E.A. D.M.E.C.N, Department De Metallurgie de Grenoble, 5 Mars 1974.

59. Besenbruch, G. E., et a1., "Diffusional Behavior of Strontium in Graphite," Trans. Amer. Nuc1. Soc. 12, 81 (1969).

60. Zumwa1t, L. R., "The Concentration Dependence of the Diffusion Coefficient of Volatile Fission Product Metals in Graphite, "Trans. Amer. Nuc1. Soc 13-2, 566-568 (1970). 